\title{
Monoterpene chemical speciation in a tropical rainforest: variation with season, height, and time of day at the Amazon Tall Tower Observatory (ATTO)
}

\author{
Ana María Yáñez-Serrano ${ }^{1, a}$, Anke Christine Nölscher ${ }^{1, b}$, Efstratios Bourtsoukidis ${ }^{1}$, Eliane Gomes Alves ${ }^{2}$, \\ Laurens Ganzeveld $^{3}$, Boris Bonn ${ }^{4}$, Stefan Wolff ${ }^{1}$, Marta Sa ${ }^{2}$, Marcia Yamasoe ${ }^{5}$, Jonathan Williams ${ }^{1}$, \\ Meinrat O. Andreae ${ }^{1,6}$, and Jürgen Kesselmeier ${ }^{1}$ \\ ${ }^{1}$ Air Chemistry, Biogeochemistry and Multiphase Departments, Max Planck Institute for Chemistry, \\ Mainz, Germany \\ ${ }^{2}$ Instituto Nacional de Pesquisas da Amazônia (INPA), Av. André Araújo 2936, Manaus, AM, Brazil \\ ${ }^{3}$ Meteorology and Air Quality (MAQ), Department of Environmental Sciences, \\ Wageningen University and Research Centre, Wageningen, the Netherlands \\ ${ }^{4}$ Tree Physiology, Albert Ludwig University, Freiburg, Germany \\ ${ }^{5}$ Instituto de Astronomia, Geofísica e Ciências Atmosféricas, Universidade de São Paulo, \\ Rua do Matão 122, São Paulo, SP, Brazil \\ ${ }^{6}$ Scripps Institution of Oceanography, University of California San Diego, La Jolla, CA, USA \\ ${ }^{a}$ now at: Ecosystem Physiology, Albert Ludwig University, Freiburg, Germany \\ b now at: German Weather Service, Offenbach am Main, Germany \\ Correspondence: Ana María Yáñez-Serrano (a.yanezserrano@mpic.de)
}

Received: 31 August 2017 - Discussion started: 19 September 2017

Revised: 23 January 2018 - Accepted: 9 February 2018 - Published: 8 March 2018

\begin{abstract}
Speciated monoterpene measurements in rainforest air are scarce, but they are essential for understanding the contribution of these compounds to the overall reactivity of volatile organic compound (VOC) emissions towards the main atmospheric oxidants, such as hydroxyl radicals $(\mathrm{OH})$, ozone $\left(\mathrm{O}_{3}\right)$ and nitrate radicals $\left(\mathrm{NO}_{3}\right)$. In this study, we present the chemical speciation of gas-phase monoterpenes measured in the tropical rainforest at the Amazon Tall Tower Observatory (ATTO, Amazonas, Brazil). Samples of VOCs were collected by two automated sampling systems positioned on a tower at 12 and $24 \mathrm{~m}$ height and analysed using gas chromatography-flame ionization detection. The samples were collected in October 2015, representing the dry season, and compared with previous wet and dry season studies at the site. In addition, vertical profile measurements (at 12 and $24 \mathrm{~m}$ ) of total monoterpene mixing ratios were made using proton-transfer-reaction mass spectrometry. The results showed a distinctly different chemical speciation between day and night. For instance, $\alpha$-pinene was more abundant during the day, whereas limonene was more
\end{abstract}

abundant at night. Reactivity calculations showed that higher abundance does not generally imply higher reactivity. Furthermore, inter- and intra-annual results demonstrate similar chemodiversity during the dry seasons analysed. Simulations with a canopy exchange modelling system show simulated monoterpene mixing ratios that compare relatively well with the observed mixing ratios but also indicate the necessity of more experiments to enhance our understanding of in-canopy sinks of these compounds.

\section{Introduction}

Isoprenoids such as isoprene $\left(\mathrm{C}_{5} \mathrm{H}_{8}\right)$, monoterpenes $\left(\mathrm{C}_{10} \mathrm{H}_{16}\right)$ and sesquiterpenes $\left(\mathrm{C}_{15} \mathrm{H}_{24}\right)$ are considered to be key contributors to the production of biogenic secondary organic aerosol (SOA), which affects cloud condensation nuclei production (Engelhart et al., 2008; Jokinen et al., 2015; Pöschl et al., 2010). While isoprene is a globally 
significant source of SOA (Claeys et al., 2004), its presence can also inhibit SOA formation under certain conditions (Kiendler-Scharr et al., 2009). By virtue of their lower volatility and higher ozone reactivity, monoterpenes and sesquiterpenes are strong sources of secondary organic aerosol (SOA) through the generation of low-volatility oxidation products formed via ozonolysis and hydroxyl radical oxidation (Bonn and Moortgat, 2003; Zhao et al., 2015).

The main source of monoterpenes in the global atmosphere is emission from vegetation, with smaller contributions from soil (Kesselmeier and Staudt, 1999; Kuhn et al., 2002; Ormeno et al., 2007). Synthesis of the monoterpene species occurs via the non-mevalonate pathway within the plant chloroplast (Kesselmeier and Staudt, 1999; Lichtenthaler, 1999; Schwender et al., 1996), which explains the light dependency also known to determine isoprene synthesis and emission. These commonly emitted compounds have been identified as important signalling compounds through plant-plant, plant-insect or plant-microbe interactions (Gershenzon, 2007; Gershenzon and Dudareva, 2007; Kishimoto et al., 2006; Maag et al., 2015) and they are thought to protect photosynthetic membranes against abiotic stresses (Jardine et al., 2017; Penuelas and Llusia, 2002; Vickers et al., 2009).

Despite having a common sum formula, variations in the molecular structure of the various monoterpenes result in large variations (over 2 orders of magnitude) of their reaction rate coefficients with the hydroxyl radicals $(\mathrm{OH})$, ozone $\left(\mathrm{O}_{3}\right)$ and nitrate radicals $\left(\mathrm{NO}_{3}\right)$. This leads to different implications for the efficiency of SOA formation (Hallquist et al., 2009; Kiendler-Scharr et al., 2009; Mentel et al., 2009; O'Dowd et al., 2002). In most cases, SOA products are poorly characterized due to a scarcity of measurements (Martin et al., 2010).

Considering the overall size of the Amazon rainforest (5.4 million $\mathrm{km}^{2}$ in 2001; Malhi et al., 2008) and the significant contribution of biogenic volatile organic compound (BVOC) emissions from this vast forest to the global volatile organic compound (VOC) budget (globally $1000 \mathrm{Tg}$ of carbon $\mathrm{yr}^{-1}$; Guenther et al., 2012), measurements of total monoterpene emissions and mixing ratios from this ecosystem are scarce (Greenberg and Zimmerman, 1984; Helmig et al., 1998; Jardine et al., 2015, 2011, 2017; Karl et al., 2007; Rinne et al., 2002; Yáñez-Serrano et al., 2015). Speciated measurements are even more rare (Jardine et al., 2015, 2017; Kesselmeier et al., 2002; Kuhn et al., 2004). However, this information is essential for our understanding of the functioning of the Amazon rainforest in atmospheric chemistry-climate interactions. Knowledge of these processes also serves to improve predictions of future changes in atmospheric composition and to assess the impact of changes in regional emissions and land use on the global climate caused by Amazon deforestation.
In this study, we evaluate measurements of speciated rainforest monoterpene mixing ratios as a function of height in the canopy, season and diel cycle. This evaluation includes a comparison with a canopy exchange modelling system (MLC-CHEM, Multi-Layer Canopy Chemistry Exchange Model) to support analysis of the measured temporal variability in speciated rainforest monoterpene mixing ratios inside the tropical rainforest canopy. The MLC-CHEM was also selected since it has been already extensively applied for site- to global-scale studies on atmosphere-biosphere exchange for tropical rainforests (Ganzeveld et al., 2002, 2008; Ganzeveld and Lelieveld, 2004; Kuhn et al., 2010).

\section{Methodology}

\subsection{Site}

The site chosen for this study was the Amazon Tall Tower Observatory, ATTO (Andreae et al., 2015). This site is located in central Amazonia $\left(02^{\circ} 08.647^{\prime} \mathrm{S}, 58^{\circ} 59.992^{\prime} \mathrm{W}\right)$, $150 \mathrm{~km}$ north-east of the closest large city, Manaus, Brazil. Due to the prevailing north-easterly wind direction, the influence of the Manaus plume is negligible and the measurements at this site can be considered to reflect pristine tropical forest conditions affected by air masses that have passed over about $1000 \mathrm{~km}$ of undisturbed rainforest. The site is equipped with a $325 \mathrm{~m}$ tall tower as well as two smaller towers. This study was carried out on the INSTANT tower, an $80 \mathrm{~m}$ walk-up tower located $600 \mathrm{~m}$ from the tall tower in an easterly direction. Sampling was performed on this tower below the canopy top (mean canopy height $35 \mathrm{~m}$ ) at two different heights (12 and $24 \mathrm{~m}$ ). For a comprehensive site description, see Andreae et al. (2015).

\subsection{Air sampling}

Collection of ambient air samples on adsorbent tubes, for subsequent analysis by a gas chromatography-flame ionization detector (GC-FID), was conducted with two automated cartridge samplers, described in earlier studies (Kesselmeier et al., 2002; Kuhn et al., 2002, 2005), positioned at 12 and $24 \mathrm{~m}$ on the INSTANT tower. The samplers consist of two main units, a cartridge magazine that holds the adsorbentfilled tubes and the control unit timing the process and recording the data. This latter unit also houses the pumps (Type N86KT, KNF Neuberger, Freiburg, Germany), pressure gauges, mass flow controllers and power supply. The cartridge magazine is equipped with solenoid valves controlling the inlet and outlet of up to 20 individual sampling adsorbent tubes. The system is a constant-flow device, with one cartridge position per loop used as a bypass for purging the system. Due to the compact weatherproof housings and the low power consumption, we were able to position one sampler at $24 \mathrm{~m}$ and the other one at $12 \mathrm{~m}$, attached to the INSTANT tower booms with commercially available $50 \mathrm{~mm}$ 
aluminium clamps. The adsorbent tubes used for VOC sampling were filled with $130 \mathrm{mg}$ of Carbograph $1\left(90 \mathrm{~m}^{2} \mathrm{~g}^{-1}\right)$ followed by $130 \mathrm{mg}$ of Carbograph $5\left(560 \mathrm{~m}^{2} \mathrm{~g}^{-1}\right)$ sorbents. The size of the Carbograph particles was in the range of 2040 mesh. Carbographs 1 and 5 were provided by L.A.R.A s.r.l. (Rome, Italy) (Kesselmeier et al., 2002). The samples were collected from 17 to 20 October 2015. Samples were taken for $30 \mathrm{~min}$ every hour at a flow of $200 \mathrm{~cm}^{3} \mathrm{~min}^{-1}$ (STP), leading to a collection of $6 \mathrm{~L}$ of air in each cartridge using the automatic sampler. Additional sampling was performed at $24 \mathrm{~m}$ with a GSA SG-10-2 personal sampler pump during the years 2012-2014. These earlier samples were collected in the same type of adsorbent tubes as for the automatic sampler and were filled at $167 \mathrm{~cm}^{3} \mathrm{~min}^{-1}$ (STP) air flow for $20 \mathrm{~min}$. These additional measurements took place on 19 and 28 November 2012; 1, 3 and 4 March 2013; 11-14 June 2013; 22, 25 and 26 September 2013 and on 17 and 21 August 2014.

\subsection{Instruments used for chemical analysis}

\subsubsection{Gas chromatography-flame ionization detector (GC-FID)}

After collection, the adsorbent tubes were analysed at the Max Planck Institute for Chemistry (MPIC), employing the gas chromatography method, using a flame ionization detector (GC-FID, Model AutoSystem XL, Perkin Elmer $\mathrm{GmbH}$, Germany) for identification and quantification of the monoterpene species. Helium was used as the carrier gas, and separation occurred on a $100 \mathrm{~m}$ HP-1 column with $0.22 \mathrm{~mm}$ inner diameter, coated with the non-polar dimethylpolysiloxane as the stationary phase. The compound mixture collected in the adsorbent tubes was discharged into the gas stream with the help of a two-step desorption system (Model ATD400, Perkin Elmer, Germany). The samples were cryofocused in a cold trap at $-30^{\circ} \mathrm{C}$ filled with Carbograph 5, providing better defined peaks in the chromatograms. Afterwards the cold trap was heated to $280^{\circ} \mathrm{C}$ and the preconcentrated sample injected onto the column. The following temperature programme was used: -10 to $40^{\circ} \mathrm{C}$ at $20^{\circ} \mathrm{C} \mathrm{min}^{-1}, 40$ to $145^{\circ} \mathrm{C}$ at $1.5^{\circ} \mathrm{C} \mathrm{min}^{-1}$ and 145 to $220^{\circ} \mathrm{C}$ at $30^{\circ} \mathrm{C} \mathrm{min}{ }^{-1}$. The separated compounds were quantified with a flame ionization detector (FID). Identification was achieved through spiked injection of pure compounds. For a more detailed description, see Kesselmeier et al. (2002).

Calibration for VOCs containing no heteroatoms was achieved by using a standard gas mixture of isoprene and several $n$-alkanes ( $n$-pentane, $n$-hexane, $n$-heptane, $n$-octane, $n$-nonane, and $n$-decane) (Apel-Riemer Environmental Inc., USA). In this case, it is assumed that the "effective carbon number" (Sternberg et al., 1962) is equal to the real carbon number of the molecules (Komenda, 2001), yielding a signal response that is proportional to the real carbon number. The monoterpenes identified and quantified were $\alpha$-pinene, camphene, sabinene, $\beta$-pinene, myrcene, $\alpha$-phellandrene, 3 carene, $\alpha$-terpinene, $\rho$-cymene, limonene and $\gamma$-terpinene. Isoprene was also quantified. The detection limit for the GCFID was 2 ppt (Bracho-Nunez et al., 2011).

\subsubsection{Proton-transfer-reaction mass spectrometer (PTR-MS)}

Online total monoterpene mixing ratios were determined by a quadrupole proton-transfer-reaction mass spectrometer, PTR-MS (Ionicon Analytic, Austria). The PTR-MS was operated under standard conditions (2.2 mbar drift pressure, $600 \mathrm{~V}$ drift voltage, with an E/N of 142 Townsend (Td)). In addition to weekly humidity-dependent calibrations, hourly background measurements were performed with a catalytic converter (Supelco, Inc. with platinum pellets heated to $>400^{\circ} \mathrm{C}$ ). A gravimetrically prepared multicomponent standard for calibration was obtained from Apel \& Riemer Environmental, USA. The measurements were carried out at two different heights (12 and $24 \mathrm{~m}$ ), with the PTR-MS switching sequentially between each height at 2 min intervals. The inlet lines were made of PTFE (9.5 mm OD), insulated and heated to $50^{\circ} \mathrm{C}$, and had PTFE particle inlet filters at the intake end. The compounds of interest for this study were isoprene $(\mathrm{m} / \mathrm{z}$ $69)$ and the sum of monoterpenes $(m / z$ 137). The limit of detection of the PTR-MS for total monoterpenes was 0.1 and $0.2 \mathrm{ppb}$ for isoprene, determined as $3 \sigma$ of the background noise. More information about the gradient system and PTRMS operation at ATTO can be found elsewhere (Nölscher et al., 2016; Yáñez-Serrano et al., 2015).

\subsection{Multi-Layer Canopy Chemistry Exchange Model (MLC-CHEM)}

To analyse the magnitude and temporal variability of the observed monoterpene concentrations inside and above the forest canopy, we applied the Multi-Layer Canopy Chemistry Exchange Model (MLC-CHEM), driven by the observed micro-meteorology and ozone surface layer mixing ratios. The MLC-CHEM was originally developed and implemented in a single-column model. It is set up also in a global chemistry- and climate-modelling system to assess the role of canopy processes in local- to global-scale atmospherebiosphere exchange of nitrogen oxides (Ganzeveld et al., 2002, 2008; Kuhn et al., 2010). The model's generalized representation of chemistry, dry deposition, emissions and turbulent mixing allows the role of canopy interactions in determining atmosphere-biosphere exchange fluxes and incanopy and surface layer mixing ratios of e.g. ozone $\left(\mathrm{O}_{3}\right)$, nitrogen oxides $\left(\mathrm{NO}_{x}\right)$ and BVOCs to be studied. The BVOC emissions are calculated according to MEGAN (Guenther et al., 2006), considering the vertical distribution of biomass and direct as well as diffuse radiation to calculate leaf-scale BVOC emissions. The current implementation of canopy chemistry in the MLC-CHEM considers, in addition to stan- 
dard photochemistry involving $\mathrm{O}_{3}, \mathrm{NO}_{x}$, methane $\left(\mathrm{CH}_{4}\right)$ and carbon monoxide (CO), the role of non-methane hydrocarbons including isoprene, and a selection of hydrocarbon oxidation products such as formaldehyde, higher aldehydes and acetone. Oxidation of the monoterpenes by $\mathrm{OH}, \mathrm{O}_{3}$ and $\mathrm{NO}_{3}$ is taken into account, but the role of the monoterpene oxidation products in photochemistry is not considered in the current implementation of the chemistry scheme in the MLCCHEM. For this study, we have extended the MLC-CHEM to consider, besides the compounds $\alpha$-pinene and $\beta$-pinene and the observed monoterpene species $\alpha$-terpinene, limonene and myrcene that are already included. The monoterpene basal leaf-scale monoterpene emission factors have been selected such that the model simulates monoterpene mixing ratios of comparable magnitude compared to the campaignaverage observed mixing ratios. In the evaluation of simulated and observed mixing ratios we mainly focus on comparison of the simulated and observed temporal variability being determined by the differences in canopy processes for contrasting nocturnal and daytime conditions. For the model simulation, the basal emission factors were $0.18 \mu \mathrm{g} \mathrm{Cg}^{-1} \mathrm{~h}^{-1}$ for $\alpha$-pinene, $0.04 \mu \mathrm{g} \mathrm{Cg} \mathrm{g}^{-1} \mathrm{~h}^{-1}$ for $\beta$ pinene, $0.11 \mu \mathrm{g} \mathrm{Cg}^{-1} \mathrm{~h}^{-1}$ for $\alpha$-terpinene, $0.9 \mu \mathrm{g} \mathrm{Cg}^{-1} \mathrm{~h}^{-1}$ for limonene and $0.18 \mu \mathrm{g} \mathrm{Cg}^{-1} \mathrm{~h}^{-1}$ for myrcene. Note the selected relative high basal emission flux for limonene is required to arrive at simulated mixing ratios comparable to the observed ones. Regarding the physical sinks, dry deposition of gases including the BVOC compounds depends on their uptake resistances calculated according to Wesely's (1989) parameterization, which estimates these uptake resistances based on the compounds' solubility and reactivity.

The simulations with the MLC-CHEM were constrained with the observed surface layer net radiation (above the canopy only), wind speed, relative humidity and $\mathrm{O}_{3}$ mixing ratios as well as the temperatures measured above and inside the canopy (eight different heights including 12 and $24 \mathrm{~m}$ ) from 17 to 20 October 2015, coinciding with the measurement dates. These simulations represent a set-up of the MLC-CHEM distinguishing six canopy levels with a canopy height of $30 \mathrm{~m}$, implying canopy layers with a thickness of $5 \mathrm{~m}$. Furthermore, we assumed a leaf area index of $5 \mathrm{~m}^{2} \mathrm{~m}^{-2}$ and a leaf area density profile such that about $70 \%$ of this biomass is present in the top $15 \mathrm{~m}$ of the canopy, as previously observed at other tropical rainforest sites (Nölscher et al., 2016). Monoterpene emissions by vegetation were simulated using a temperature-only dependent emission flux as a function of the amount of biomass in each layer and the measured canopy temperature profiles interpolating between the 0.4 and $26 \mathrm{~m}$ temperature sensors. Meteorological observations for 18 October were missing and therefore the MLCCHEM was constrained for this day by first-order estimates of the diurnal cycles in radiation, air and surface temperatures, relative humidity and wind speed comparable to the previous and subsequent days' meteorological conditions.

\section{Results and discussion}

\subsection{Time series and diel cycles}

The continuous online PTR-MS measurements were compared with offline GC-FID samples over the course of 3 days in October 2015 (Fig. 1). The close agreement between the two measurement techniques provides confidence that almost all monoterpenes present in ambient air at the site were being measured. Note that in this comparison, $\rho$-cymene (an aromatic monoterpene) was removed from the calculations as the PTR-MS does not detect it on $m / z$ 137. The observed differences in the monoterpene chemodiversity in the rainforest canopy atmosphere were regarded to be driven by differences in emission, reactivity with the oxidizing species, physical removal processes and turbulent mixing conditions.

The total monoterpene mixing ratios were higher during the day, when temperature and solar radiation were at their maxima. Most of the observed distinct diurnal cycle in total monoterpene mixing ratios could be attributed to $\alpha$-pinene, which was the dominant species during daytime (09:00 to 17:00), with mixing ratios as large as (average \pm standard deviation) $0.33 \pm 0.04$ and $0.38 \pm 0.21 \mathrm{ppb}$ at 12 and $24 \mathrm{~m}$ respectively, and $0.15 \pm 0.05$ and $0.11 \pm 0.06 \mathrm{ppb}$ for the night (20:00 to 05:00) at 12 and $24 \mathrm{~m}$. The second most abundant monoterpene species was limonene, with observed average daytime mixing ratios of $0.18 \pm 0.09$ and $0.19 \pm 0.12 \mathrm{ppb}$ at 12 and $24 \mathrm{~m}$, respectively, and $0.18 \pm 0.01$ and $0.14 \pm 0.07 \mathrm{ppb}$ for the night-time at 12 and $24 \mathrm{~m}$.

When comparing our results to previously published studies, we observed consistent differences with other regions of the Amazon rainforest. For instance, Kesselmeier et al. (2002) studied the seasonal monoterpene speciation in the Rondonia rainforest in southern Amazonia. Even though they found the same monoterpene species as presented in this study, their individual abundances were very different compared to the mixing ratios for the dry season at the ATTO site. $\alpha$-Pinene and limonene were much higher at ATTO than in Rondonia, whereas camphene was substantially lower. In the case of $\beta$-pinene, the abundance measured at ATTO was much lower than at other Amazonian sites (Andreae et al., 2002; Karl et al., 2007). Given that emission patterns are highly dependent on species, environmental conditions and stresses, these differences underline that it cannot be assumed that the same speciation and emission rates of monoterpenes exist throughout the vast Amazon basin.

Furthermore, the difference between the 12 and $24 \mathrm{~m}$ height total monoterpene mixing ratios was minor given the variance of the measurements, but there was a tendency for the difference to be more pronounced during night-time (Table 1). These more pronounced differences between the measurement heights could also be due to an enhanced sensitivity of nocturnal mixing ratios to small changes in source and sink terms for the suppressed mixing conditions prevailing during the night-time. 
(a)
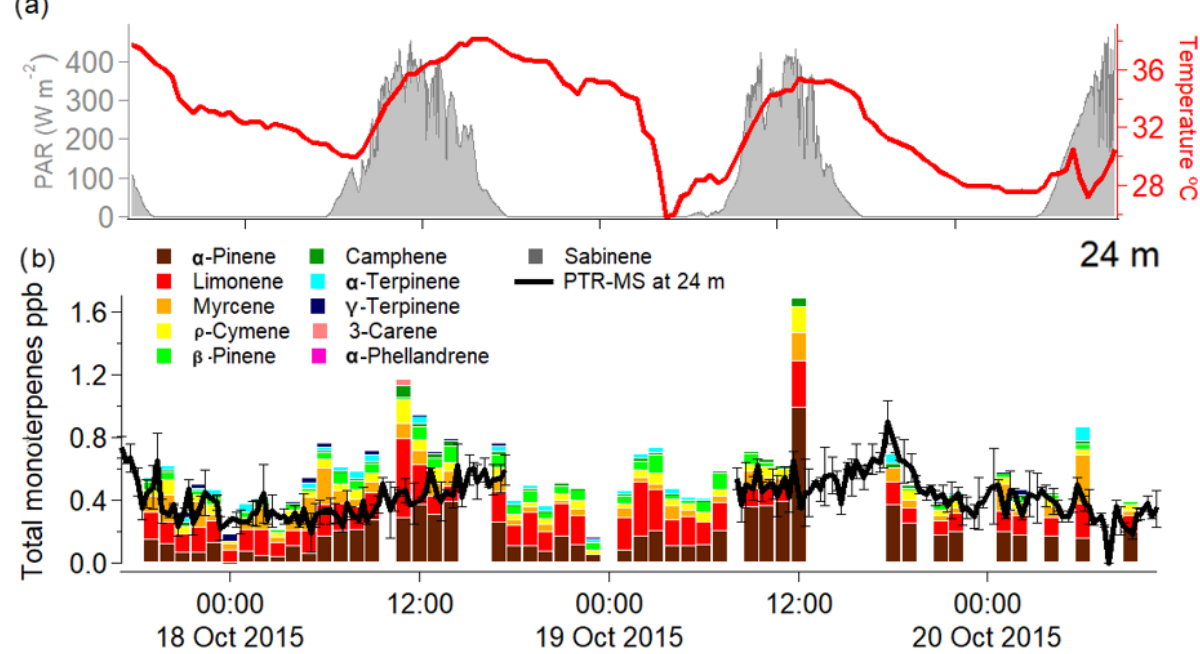

(c)

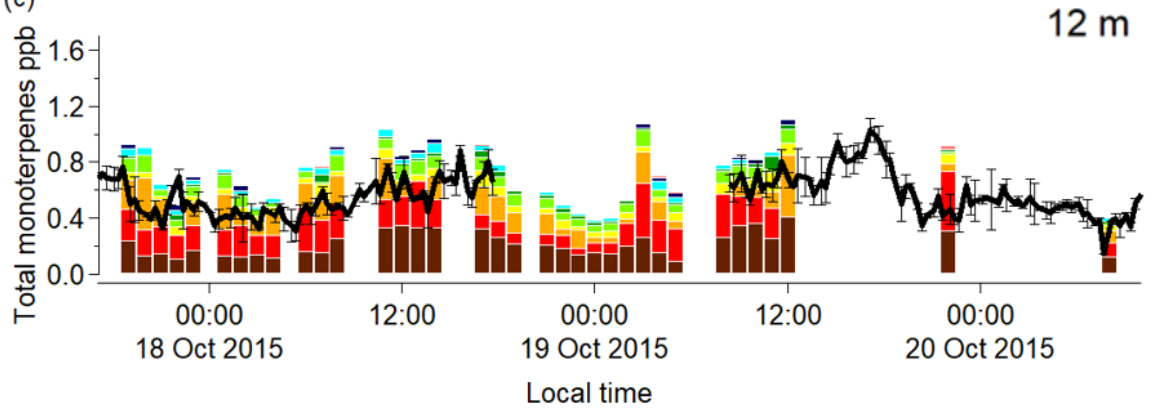

Figure 1. Graph showing the speciated monoterpene mixing ratios measured hourly from 17 to 20 October 2015 for $24 \mathrm{~m}$ (b) and $12 \mathrm{~m}$ (c). The colours on the stacked bar plot indicate the different monoterpene species as they are denoted in the legend. The black line represents the PTR-MS total monoterpene mixing ratio, with a gap of data on the 19 October 2015 . Temperature at $80 \mathrm{~m}$ is shown as the red thick line, and photosynthetically active radiation at $39 \mathrm{~m}$ is shown by the shaded areas (a).

Table 1. Average mixing ratio with standard deviation in ppb at 24 and $12 \mathrm{~m}$ of the measured monoterpene species from 17 to 20 October 2015 as determined by the GC-FID analysis. The daytime period was chosen from 09:00 to 17:00 and the night-time period from 20:00 to 05:00 (local time). "BLD" stands for values below the detection limit. "MT sum" stands for the sum of monoterpenes.

\begin{tabular}{lrrrr}
\hline Compound & Day $12 \mathrm{~m}$ & Night $12 \mathrm{~m}$ & Day $24 \mathrm{~m}$ & Night $24 \mathrm{~m}$ \\
\hline$\alpha$-pinene & $0.33 \pm 0.04$ & $0.15 \pm 0.05$ & $0.38 \pm 0.21$ & $0.11 \pm 0.06$ \\
Limonene & $0.18 \pm 0.09$ & $0.18 \pm 0.10$ & $0.19 \pm 0.12$ & $0.14 \pm 0.07$ \\
Myrcene & $0.16 \pm 0.14$ & $0.12 \pm 0.09$ & $0.09 \pm 0.04$ & $0.07 \pm 0.06$ \\
P-cymene & $0.07 \pm 0.03$ & $0.04 \pm 0.01$ & $0.08 \pm 0.04$ & $0.04 \pm 0.02$ \\
$\beta$-pinene & $0.08 \pm 0.03$ & $0.06 \pm 0.03$ & $0.05 \pm 0.03$ & $0.04 \pm 0.02$ \\
Camphene & $0.03 \pm 0.03$ & $0.02 \pm 0.01$ & $0.03 \pm 0.02$ & $0.01 \pm 0.01$ \\
$\alpha$-terpinene & $0.03 \pm 0.02$ & $0.03 \pm 0.02$ & $0.01 \pm 0.02$ & $0.02 \pm 0.02$ \\
$\gamma$-terpinene & $0.02 \pm 0.01$ & $0.01 \pm 0.01$ & $0.01 \pm 0.01$ & $0.01 \pm 0.01$ \\
3-carene & $0.001 \pm 0.003$ & $0.003 \pm 0.008$ & $0.003 \pm 0.011$ & 0 or BLD \\
$\alpha$-phellandrene & 0 or BLD & 0 or BLD & 0 or BLD & 0 or BLD \\
Sabinene & 0 or BLD & 0 or BLD & 0 or BLD & 0 or BLD \\
\hline MT sum - GC-FID & $0.91 \pm 0.10$ & $0.62 \pm 0.19$ & $0.82 \pm 0.34$ & $0.45 \pm 0.13$ \\
MT sum - PTR-MS & $0.96 \pm 0.27$ & $0.54 \pm 0.17$ & $0.77 \pm 0.22$ & $0.56 \pm 0.16$ \\
\hline & & & &
\end{tabular}




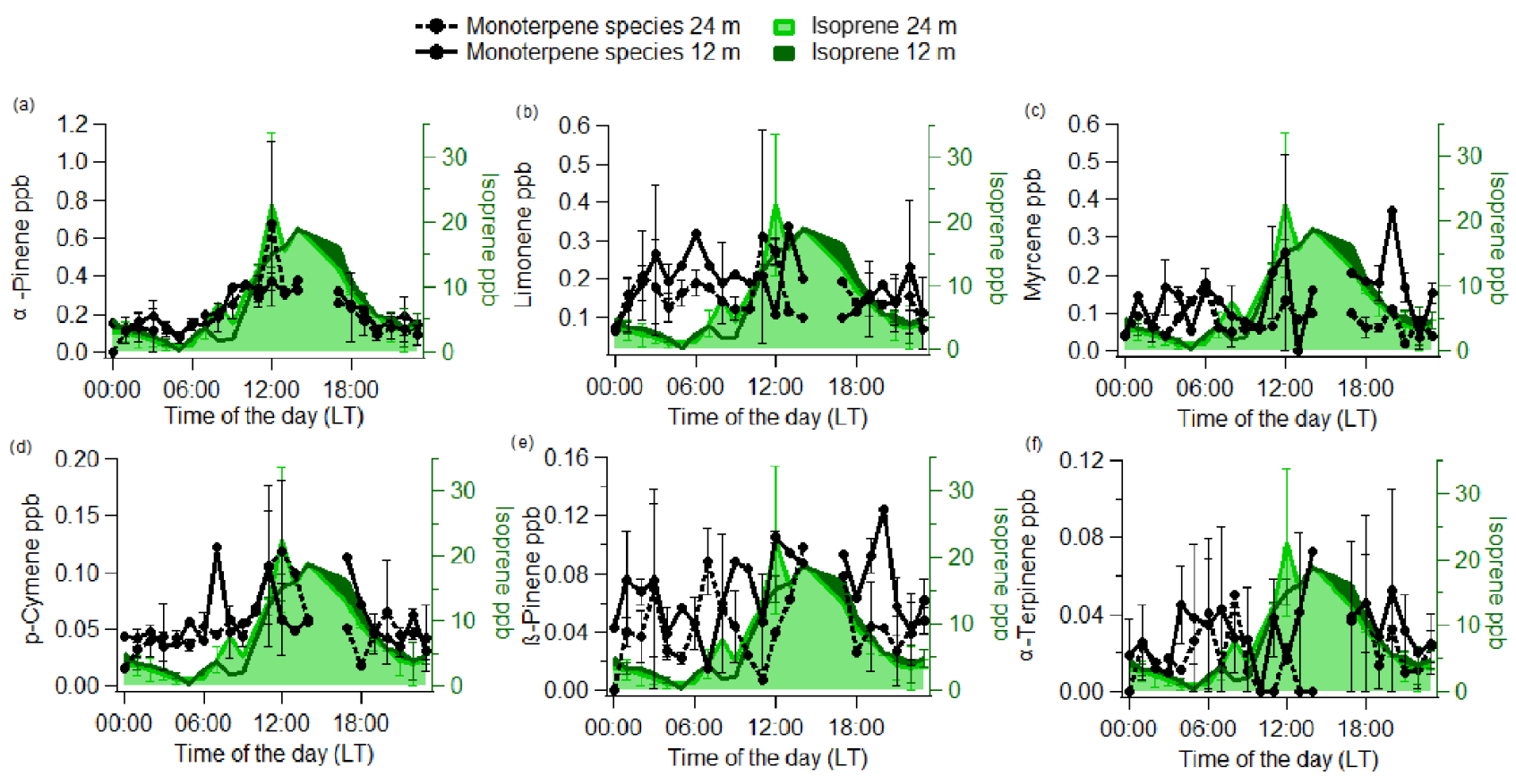

Figure 2. Average diel cycles for $\alpha$-pinene (a), limonene (b), myrcene (c), $\rho$-cymene (d), $\beta$-pinene (e) and $\alpha$-terpinene (f) mixing ratios for $24 \mathrm{~m}$ (dashed line) and $12 \mathrm{~m}$ (thick line). In the background, average diel cycles of isoprene mixing ratios as measured by the GC-FID are shown for $24 \mathrm{~m}$ (light green) and $24 \mathrm{~m}$ (dark green). Error bars represent the standard deviation of the averages.

The continuous online measurements by the quadrupole PTR-MS indicated a clear diurnal cycle in the measured mixing ratios of the sum of monoterpenes, which has been reported previously from this site (Yáñez-Serrano et al., 2015). In order to assess the effect of each individual monoterpene species, we further investigated their diurnal cycles as obtained by the offline GC-FID samples. The measured diel cycles for the most relevant monoterpene species at the ATTO site were very similar at both heights. We also compared the measured diel cycle of isoprene as measured by the GC-FID with the observed diel cycle for the different monoterpene species for 12 and $24 \mathrm{~m}$. The compounds that showed a diurnal cycle similar to isoprene were $\alpha$-pinene and $\rho$-cymene (Fig. 2). This could be due to the emission of $\alpha$-pinene and $\rho$-cymene being dependent on light and temperature, analogous to isoprene. However, during the night, both monoterpenes were also present, albeit at lower mixing ratios, and the nocturnal mixing ratios of the monoterpenes did not decrease as much as isoprene. This has also been noted in previous studies (Yáñez-Serrano et al., 2015).

Despite the higher mixing ratios of limonene compared to other monoterpene species (other than $\alpha$-pinene), it was not possible to distinguish any clear diel pattern in the average data for this species (see Fig. 2). $\beta$-Pinene and $\alpha$-terpinene likewise showed no obvious diel pattern in the rainforest air but were found to be above the detection limit of the GC-FID of 2 ppt.

In contrast to plant species of cooler climates, such as spruce, which emit terpenes from pools (Ghirardo et al.,
2010; Lerdau et al., 1997), Amazonian plant species have been found to show an emission dependency on light and temperature (Bracho-Nunez et al., 2013; Jardine et al., 2015; Kuhn et al., 2002, 2004). This could partly explain the diurnal pattern of $\alpha$-pinene mixing ratios, which exhibit some relation to a light- and temperature-dependent emission flux (Kuhn et al., 2002; Rinne et al., 2002; Williams et al., 2007). However, this behaviour was not observed for all monoterpene species. Therefore, the observed diurnal cycles of some monoterpene species might be related to a stronger temperature response.

\subsection{Chemodiversity}

The chemical speciation (or chemodiversity) of monoterpenes relates to the relative abundances of the different monoterpene species in the sampled air. $\alpha$-Pinene, limonene, myrcene, $\rho$-cymene and $\beta$-pinene represented more than $85 \%$ of the total monoterpene mixing ratio (Fig. 3). During the day (09:00 to 17:00) $\alpha$-pinene had an average abundance (average \pm standard deviation) of $46 \pm 25$ and $36 \pm 4 \%$ of the total monoterpene mixing ratios at 24 and $12 \mathrm{~m}$, respectively, and it was the dominant monoterpene in this study overall. However, during the night (20:00 to 05:00), its relative abundance dropped to $25 \pm 13$ and $25 \pm 9 \%$ at 24 and $12 \mathrm{~m}$, respectively. In contrast, limonene made up $23 \pm 15$ and $20 \pm 10 \%$ of the monoterpenes at 24 and $12 \mathrm{~m}$, respectively, by day, and increased during night-time to $33 \pm 15$ and $26 \pm 16 \%$ at 24 and $12 \mathrm{~m}$. Thus, there was a tendency to- 
(a)

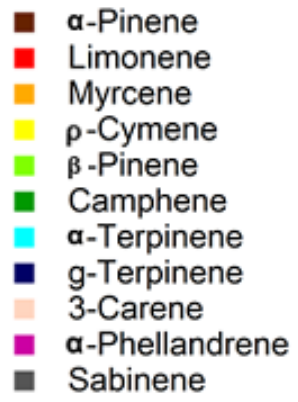

(c)
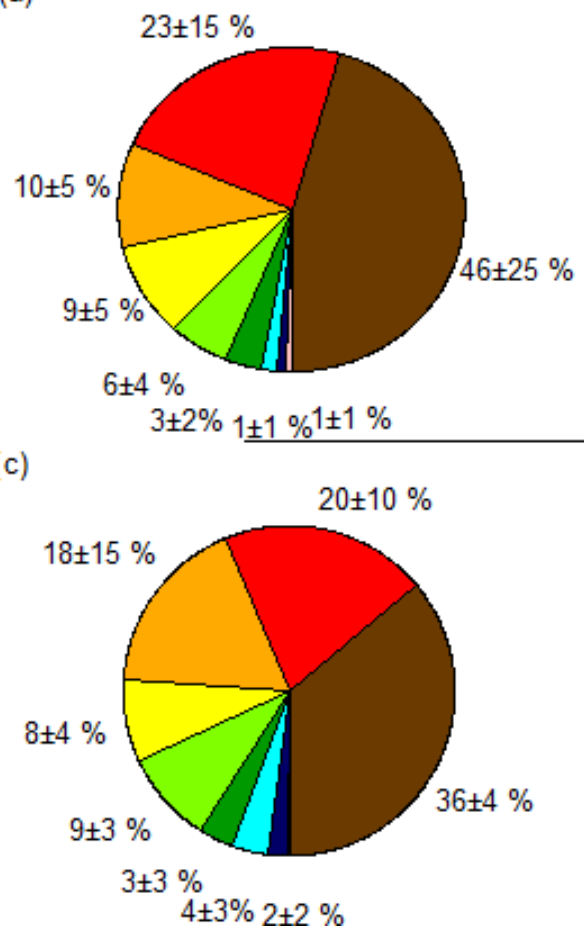

(b)

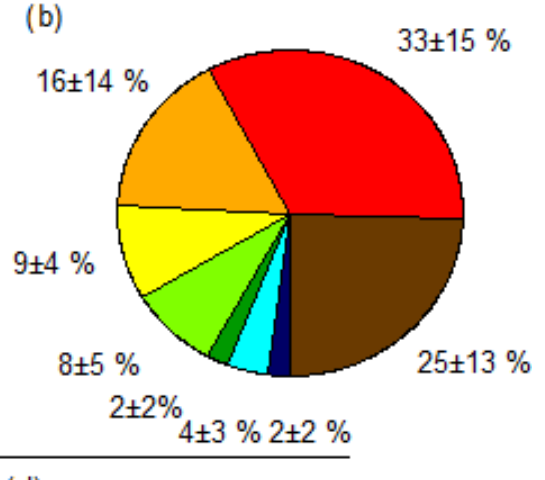

(d)

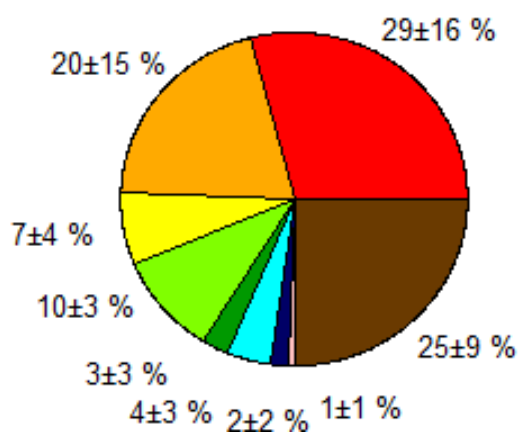

Figure 3. Pie charts representing the daytime $(\mathbf{a}, \mathbf{c})$ and night-time (b, d) average monoterpene species' abundances from 17 to 20 October 2015, with the average percentages and standard deviations at $24(\mathbf{a}, \mathbf{b})$ and $12 \mathrm{~m}(\mathbf{c}, \mathbf{d})$. The day period was from 09:00 to 17:00 and the night period was from 20:00 to 05:00.

wards some differences in monoterpene species' abundances between day- and night-time. These were mainly due to the nocturnal decreases in $\alpha$-pinene and the nocturnal relative increase in limonene. It is plausible that the observed decrease in $\alpha$-pinene mixing ratios could be due to decreased vegetation emission, as reduced chemical destruction due to very low $\mathrm{OH}$ concentrations at night would lead to an increase in the nocturnal $\alpha$-pinene mixing ratios.

Even though there were clear differences between the absolute and relative abundances of some monoterpene species during the day and night, there were no clear changes in the vertical gradients (e.g. for $\alpha$-pinene, night-time averages were $0.15 \pm 0.05 \mathrm{ppb}$ for $12 \mathrm{~m}$ and $0.11 \pm 0.06 \mathrm{ppb}$ at $24 \mathrm{~m}$ ). For the day, the apparent difference in the abundance of $\alpha$ pinene was due to a single outlier data point covering $30 \mathrm{~min}$ at noon on 19 October 2015 at $24 \mathrm{~m}$, when the $\alpha$-pinene mixing ratio doubled. This increase could not be explained, although it could be related to a strong change in wind speed an hour before the measurement, when the wind was blowing from the north. In general, our observations indicate that the abundance of monoterpene species does not vary much over the heights selected (12 and $24 \mathrm{~m}$ ) within the canopy. This is consistent with the results by Kesselmeier et al. (2000), where the monoterpene composition at the rainforest floor was comparable to the above-canopy composition at their site.

\subsection{Reactivity}

The variability of the oxidants $\left(\mathrm{OH}, \mathrm{O}_{3}\right.$ and $\left.\mathrm{NO}_{3}\right)$ present in the Amazon air is important when considering the impact that monoterpenes can have on the oxidative regime in the Amazon region and Brazil in general. Hydroxyl radicals are produced mainly during the day via ozone photolysis. Low levels of $\mathrm{OH}$ can also be generated by the reaction of ozone with doubly bonded species (e.g. monoterpenes and sesquiterpenes), even at night. In this assessment, we considered the monoterpene contributions to $\mathrm{OH}$ reactivity by day only. In contrast, $\mathrm{NO}_{3}$ is photolytically destroyed during the day but can become significant at night, so we assessed the impact of monoterpenes on $\mathrm{NO}_{3}$ reactivity at night. Even though in the Amazon rainforest ozone levels are low $(\sim 10-20 \mathrm{ppb})$ compared to other areas of the world (e.g. Williams et al., 2016), ozone is nevertheless present, and some monoterpenes are extremely reactive towards ozone. Table 2 gives an overview of the lifetime and reactivity (which is defined as the reaction rate constant (oxidant i.e. $\mathrm{OH})^{*}[$ monoterpene species]) to $1 \mathrm{ppb}$ of all the investigated monoterpene species for these three oxidants. For calculating the lifetime of the different monoterpenes as presented in Table 2, typical oxidant concentrations for the Amazon rainforest conditions were used. For $\mathrm{OH}$ a mean value of $7 \times 10^{5}$ molecules $\mathrm{cm}^{-3}$ was used as being represen- 
Table 2. Lifetime of the different monoterpene species related to $\mathrm{OH}, \mathrm{O}_{3}$ and $\mathrm{NO}_{3}$ for the $\mathrm{OH}$ daytime conditions at 24 and $12 \mathrm{~m}$. In addition, the normalized reactivity to $1 \mathrm{ppb}$ of the different monoterpene species is calculated.

\begin{tabular}{llrr|rrrr}
\hline $\begin{array}{l}\text { Monoterpenes } \\
\text { investigated }\end{array}$ & Formula & \multicolumn{3}{c|}{ Lifetime (minutes) } & \multicolumn{3}{c}{$\begin{array}{c}\text { Normalized reactivity } \\
\text { to } 1 \mathrm{ppb} \mathrm{s}^{-1}\end{array}$} \\
\cline { 2 - 7 } & & $\mathrm{OH}$ & $\mathrm{O}_{3}$ & $\mathrm{NO}_{3}$ & $\mathrm{OH}$ & $\mathrm{O}_{3}$ & $\mathrm{NO}_{3}$ \\
\hline$\alpha$-pinene & $\mathrm{C}_{10} \mathrm{H}_{16}$ & 449 & 615 & 250 & 1.42 & $2.3 \times 10^{-6}$ & 0.17 \\
Camphene & $\mathrm{C}_{10} \mathrm{H}_{16}$ & 447 & 57422 & 2461 & 1.43 & $2.4 \times 10^{-8}$ & 0.02 \\
Sabinene & $\mathrm{C}_{10} \mathrm{H}_{16}$ & 400 & 623 & 155 & 1.60 & $2.2 \times 10^{-6}$ & 0.27 \\
$\beta$-pinene & $\mathrm{C}_{10} \mathrm{H}_{16}$ & 320 & 3445 & 618 & 2.00 & $4.0 \times 10^{-7}$ & 0.07 \\
Myrcene & $\mathrm{C}_{10} \mathrm{H}_{16}$ & 71 & 110 & 141 & 8.98 & $1.3 \times 10^{-5}$ & 0.30 \\
$\alpha$-phellandrene & $\mathrm{C}_{10} \mathrm{H}_{16}$ & 132 & 17 & 21 & 4.84 & $8.1 \times 10^{-5}$ & 1.96 \\
3-carene & $\mathrm{C}_{10} \mathrm{H}_{16}$ & 271 & 1397 & 170 & 2.37 & $9.9 \times 10^{-7}$ & 0.24 \\
$\alpha$-terpinene & $\mathrm{C}_{10} \mathrm{H}_{16}$ & 103 & 2 & 11 & 6.24 & $5.6 \times 10^{-4}$ & 3.76 \\
$\rho$-cymene & $\mathrm{C}_{10} \mathrm{H}_{14}$ & 1577 & $>90000$ & $>90000$ & 0.41 & $1.3 \times 10^{-9}$ & $2.7 \times 10^{-5}$ \\
Limonene & $\mathrm{C}_{10} \mathrm{H}_{16}$ & 145 & 246 & 127 & 4.41 & $5.6 \times 10^{-6}$ & 0.33 \\
$\gamma$-terpinene & $\mathrm{C}_{10} \mathrm{H}_{16}$ & 140 & 369 & 53 & 4.57 & $3.8 \times 10^{-6}$ & 0.78 \\
\hline Isoprene & $\mathrm{C}_{5} \mathrm{H}_{8}$ & 238 & 4069 & 238 & 2.69 & $3.4 \times 10^{-7}$ & 0.02 \\
\hline
\end{tabular}

tative of the site (Spivakovsky et al., 2000). For ozone reactivity calculations, $12 \mathrm{ppb}$ was used, as this mixing ratio was observed during the measurement period. $\mathrm{NO}_{3}$ mixing ratios were taken from the MLC-CHEM simulations that predicted mixing ratios of $\sim 0.4$ ppt.

While $\alpha$-pinene, limonene and myrcene were the most abundant species, their relative contribution to total monoterpene reactivity was not proportional to their abundances. The most abundant monoterpene, $\alpha$-pinene, was not the dominant sink for the oxidants. In particular, $\alpha$-terpinene dominated ozone reactivity associated with monoterpene abundance both during the day and night, as well as the nocturnal nitrate reactivity, despite the low mixing ratios measured for this compound (Table 2).

The monoterpene ozone reactivity was comparable between day $\left(1.37 \times 10^{-6} \mathrm{~s}^{-1}\right)$ and night $\left(1.12 \times 10^{-6} \mathrm{~s}^{-1}\right)$. $\alpha$ Terpinene dominated the monoterpene-ozone chemistry, followed by myrcene and limonene. Despite the relatively high abundance of $\alpha$-pinene ( $46 \pm 25 \%$; average mixing ratio and standard deviation during the day was $0.34 \pm 0.04 \mathrm{ppb}$ at $12 \mathrm{~m}$ ), its contribution to ozone reactivity with respect to other monoterpene species was only $11 \pm 7$ and $3 \pm 1 \%$ at $24 \mathrm{~m}$, during the day and night, respectively, and $2 \pm 1 \%$ for both day and night at $12 \mathrm{~m}$ (Fig. 4). As previously noted, the differences in ozone reactivity between heights were negligible for the night and slightly higher at $24 \mathrm{~m}$ during the day. As ozone mixing ratios are quite similar for both heights during the day and night (11.4 ppb at $12 \mathrm{~m}$ and $10.4 \mathrm{ppb}$ at $24 \mathrm{~m}$ during the night, and $16.1 \mathrm{ppb}$ at $12 \mathrm{~m}$ and 15.6 at $24 \mathrm{~m}$ during the day), the higher abundance of $\alpha$-pinene during the day and the lower $\alpha$-terpinene mixing ratios at $24 \mathrm{~m}$ during the day mainly explain these changes in monoterpene-ozone reactivity. It is important to note that these results are de- rived from a relative abundance analysis, and unmeasured monoterpene species could change the proportions, although given the close similitude between PTR-MS and GC-FID measurements shown in Fig. 1, this is unlikely. On the other hand, very reactive species, which could dominate reactivity, may be present in very low concentrations, for which our measurements' capabilities would not allow detection.

The monoterpene reactivity towards the $\mathrm{NO}_{3}$ radical during the night was also dominated by $\alpha$-terpinene $(40 \pm 36$ and $42 \pm 27 \%$, for 24 and $12 \mathrm{~m}$, respectively), although contributions of limonene $(30 \pm 13$ and $25 \pm 14 \%$, for 24 and $12 \mathrm{~m}$, respectively), $\alpha$-pinene (11 \pm 6 and $11 \pm 4 \%$, for 24 and $12 \mathrm{~m}$, respectively), and myrcene $(13 \pm 11$ and $16 \pm 12 \%$, for 24 and $12 \mathrm{~m}$, respectively) were also significant. No significant differences between the reactivities at different heights were observed, suggesting a rather homogeneous chemical regime regarding monoterpene chemical destruction within the canopy (from 12 to $24 \mathrm{~m}$ ). However, note that this finding reflects the use of a single simulated $\mathrm{NO}_{3}$ mixing ratio due to the absence of direct measurements in the Amazon rainforest, which prevents us from drawing any further conclusions. Our $\mathrm{OH}$ reactivity estimates demonstrate the important role of myrcene, with its higher reactivity towards $\mathrm{OH}$ due to its acyclic nature, especially at $12 \mathrm{~m}$, where myrcene was more abundant. The total $\mathrm{OH}$ reactivity for the sum of monoterpenes was calculated to be 2.4 and $3.4 \mathrm{~s}^{-1}$ for 24 and $12 \mathrm{~m}$, respectively.

As demonstrated in this data set, chemically speciated measurements are very important for understanding how monoterpenes affect Amazon air chemistry, dependent on the time of day and season, as each monoterpene species has a different reactivity. Therefore, a lower abundance of a certain monoterpene species could not necessarily be related to 
Ozone reactivity for day (left) and night (right)

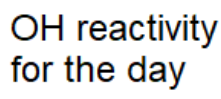

\section{$\mathrm{NO}_{3}$ reactivity \\ for the night}

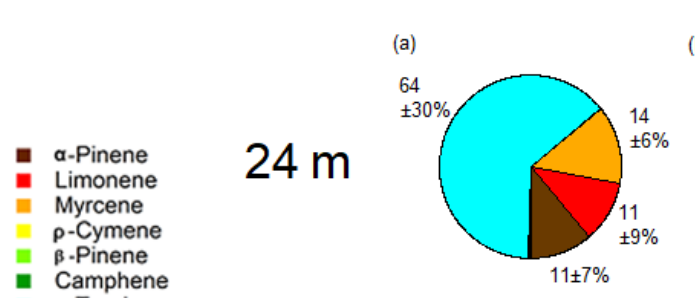

(e)

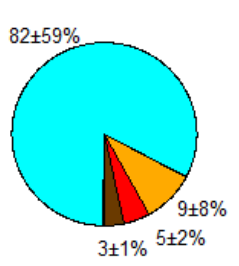

(b)

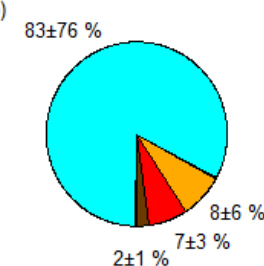

(f)

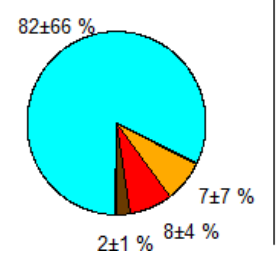

(c)

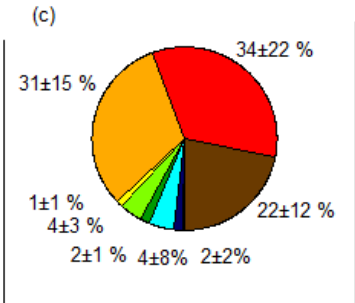

(g)

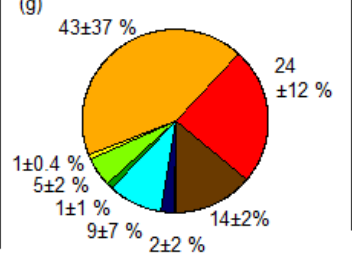

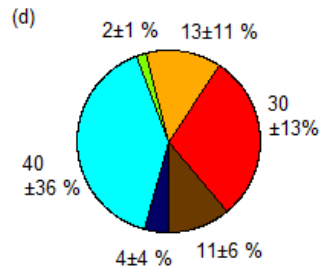

(h)

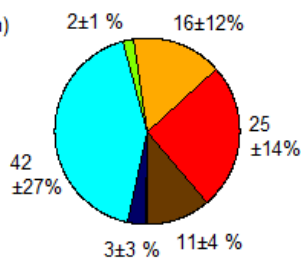

Figure 4. Pie charts representing day-time (a, e) and night-time (b, f) ozone reactivity, $\mathrm{OH}$ reactivity (only for day, $\mathbf{c}$ and $\mathbf{g}$ ) and $\mathrm{NO}_{3}$ reactivities from 17 to 20 October 2015, with the average percentages and standard deviations (only for night, $\mathbf{d}$ and $\mathbf{h}$ ), for $12 \mathrm{~m}$ on the bottom and $24 \mathrm{~m}$ on the top. The day period was from 09:00 to 17:00 and the night period was from 20:00 to 05:00.

a lower vegetation emission but also to a higher reactivity with atmospheric oxidants. Despite the small amount of $\alpha$ terpinene present in the atmosphere, it can profoundly affect reactivity due to its fast reaction rate (its lifetime, according to the oxidant mixing ratios stated above, can be 103, 2 and 11 min to $\mathrm{OH}, \mathrm{O}_{3}$ and $\mathrm{NO}_{3}$, respectively; Neeb et al., 1997). In terms of total OH reactivity accounted for by the monoterpenes, the values of this study are very low compared to the total $\mathrm{OH}$ reactivity measurements by Nölscher et al. (2016), with a mean total $\mathrm{OH}$ reactivity for the dry season of $32 \mathrm{~s}^{-1}$, mostly dominated by isoprene chemistry. This suggests that the monoterpenes contributed only a small fraction to the total $\mathrm{OH}$ reactivity at the ATTO site during the investigated time period. This study demonstrates that the abundance does not relate to the importance in chemical reactivity, and species that are usually not considered by atmospheric chemistry models due to their modest mixing ratios might actually play a dominant role in the monoterpene atmospheric chemistry. Therefore, it is questionable to generalize the representation of terpene chemistry in models (Hallquist et al., 2009) using one or two monoterpene species only.

The gas-phase oxidation of the monoterpenes in the Amazon has numerous impacts on the environment, including the production of a multitude of new compounds that are generally longer lived than the primary emissions, increasing the lifetimes and particle production potential of certain compounds by suppressing oxidant availability. Moreover, production of $\mathrm{OH}$ due to the ozonolysis of monoterpenes is known to occur (Paulson et al., 1999). The production strength varies depending on the position of the double bonds, if there is more than one (Herrmann et al., 2010).
Furthermore, the products of the reaction can be manifold. For instance, when $\alpha$-pinene is oxidized by $\mathrm{OH}$, especially at low nitrogen oxide mixing ratios, pinonaldehyde is formed in high yields (Eddingsaas et al., 2012). Chemical processing of $\alpha$-pinene can also result in a further production of different monoterpenes such as the reaction of $\alpha$-pinene with nitrate during the night, which can lead to the formation of $\rho$-cymene (Gratien et al., 2011).

The implications of the measured monoterpene abundances for SOA formation at the ATTO site are difficult to quantify because the SOA formation yield is dependent on many factors. For example, it depends on the pre-existing organic aerosol mass into which these products can be absorbed (Griffin et al., 1999), and thus the SOA yield can vary between regions with similar monoterpene mixing ratios and different aerosol mass loadings. It also varies strongly between different oxidants and terpene species. For instance, $\alpha$-pinene forms negligible aerosol mass under $\mathrm{NO}_{3}$ oxidation (Fry et al., 2014), whereas there is production of organic aerosols when the oxidation of $\alpha$-pinene involves $\mathrm{O}_{3}$ (Ehn et al., 2014) and $\mathrm{OH}$ (Eddingsaas et al., 2012). Monoterpenes containing endocyclic double bonds (e.g. $\alpha$-pinene, 3 -carene) or open chains (e.g. myrcene) tend to form less aerosol mass from ozonolysis than monoterpenes with exocyclic double bonds (e.g. $\beta$-pinene, sabinene; Hatakeyama et al., 1989; Hoffmann et al., 1997). Following the equation established by Bonn et al. (2014, Eq. 5 in text), we were able to estimate the potential aerosol particle number formation rate initiated by monoterpene species only $\left(1 \times 10^{-5}\right.$ to $5 \times 10^{-5} \mathrm{~cm}^{-3} \mathrm{~s}^{-1}$ at $24 \mathrm{~m}$ ) assuming steady-state conditions for radicals. Those were found to be approximately 2 orders of magnitudes smaller than the calculated potential new 


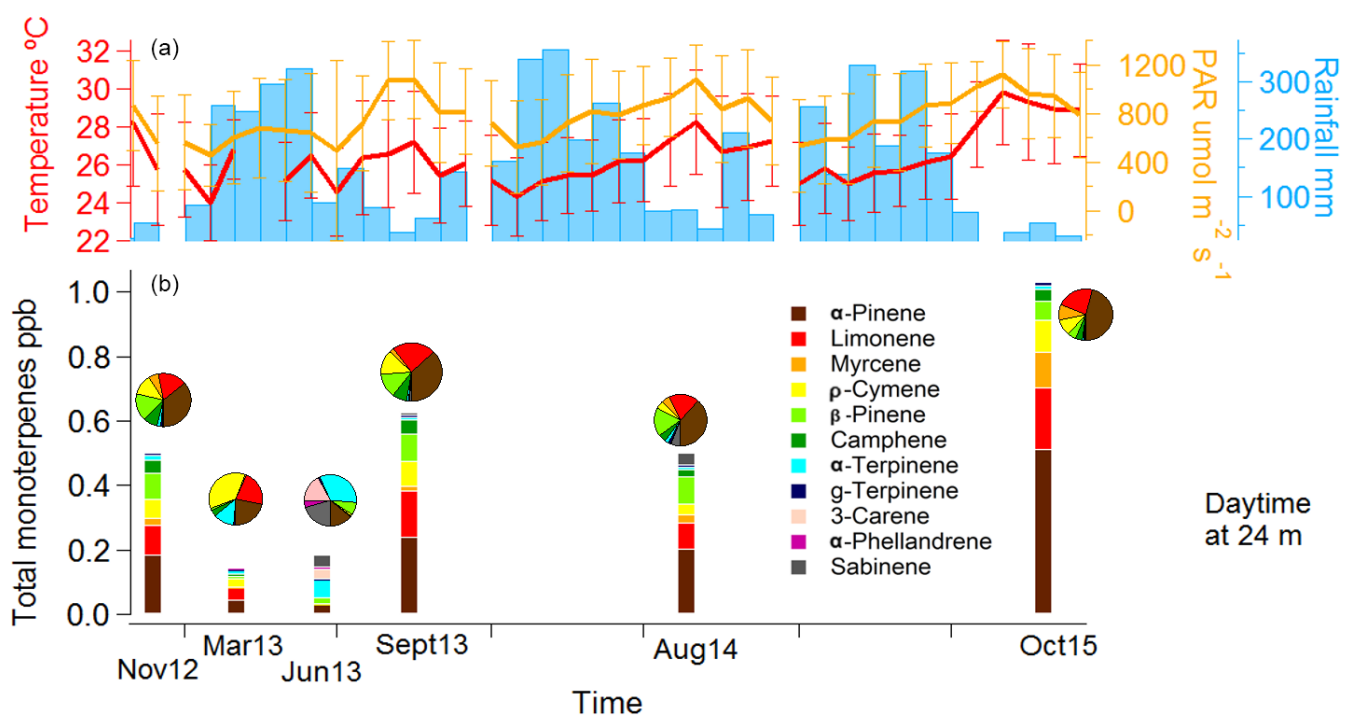

Figure 5. Monoterpene mixing ratio chemical speciation during the seasons of measurement. In (a), the monthly average of temperature (in red) and photosynthetically active radiation (in orange) are displayed with their standard deviations for the $80 \mathrm{~m}$ height. Rain, also in (a), is displayed in millimetres per month (bars). In (b), the different monoterpene species are differentiated by colours, stacked together, adding up to the sum of monoterpenes. Above each bar, a pie chart with the chemical speciation is shown for easier visualization.

aerosol particle formation rate caused by oxidation products of sesquiterpenes. Our calculations assume mixing ratios of sesquiterpenes of $0.2 \mathrm{ppb}$, revealing potential formation rates of $1 \times 10^{-3}$ and $4.5 \times 10^{-3} \mathrm{~cm}^{-3} \mathrm{~s}^{-1}$ at $24 \mathrm{~m}$ based on previous measurements in the Amazon (Jardine et al., 2011), which are remarkably smaller than observed at mid-latitude conditions (Bonn et al., 2014). Furthermore, the level of NO present (nitric oxide) also affects the potential aerosol growth (Wildt et al., 2014) and yield (Sarrafzadeh et al., 2016) at low $\mathrm{BVOC} / \mathrm{NO}_{x}$ ratios. As the theory assumes contributions of larger organic peroxy radicals $\left(\mathrm{RO}_{2}\right)$, which are destroyed by reactions, e.g. with $\mathrm{NO}$, increasing $\mathrm{NO}_{x}$ at a constant $\mathrm{BVOC}$ mixing ratio will decrease the $\mathrm{BVOC} / \mathrm{NO}_{x}$ ratio and lead to a decline in SOA yield. Our calculations showed this effect, with a change of NO from 0.2 to $1 \mathrm{ppb}$, leading to a decrease in the formation rate at a diameter of $3 \mathrm{~nm}$. This interdependence calls for a consistent consideration of the BVOC and $\mathrm{NO}_{x}$ exchange in aerosol formation and growth studies.

\subsection{Seasonality}

By examining GC-FID data collected in previous campaigns, an intra- and inter-annual comparison can be made. Total monoterpene averages for each season were calculated from 11:00 to 16:00 at $24 \mathrm{~m}$. Based on these data, we distinguished the monoterpene mixing ratios representative of the dry season, the wet season and the wet-dry transition. The dry season conditions were represented by measurements collected in November 2012, September 2013 and August 2014, and the measurements from this study were collected in October 2015. The wet season measurements were collected in March 2013 and the wet-dry transition measurements were collected in June 2013. For the dry season conditions, the total monoterpene mixing ratios were substantially higher $(1.02 \mathrm{ppb})$ compared to the observed monoterpene mixing ratios in the wet season $(0.14 \mathrm{ppb})$ and the wet-dry transition season (0.18 ppb) (Fig. 5). This coincides with the occurrence of the highest radiation levels and temperatures as well as the lowest precipitation during these dry season measurement campaigns. During the wet season, the total monoterpene mixing ratios were lowest, while during the transition season in June, they were slightly higher.

For each season, an average monoterpene chemodiversity distribution is shown in Fig. 5. During the dry seasons, the chemodiversity seems relatively similar $(39.4 \pm 4 \%$ for $\alpha$ pinene, $20.3 \pm 3 \%$ for limonene), whereas it slightly changes during the wet season and dramatically changes during the wet-dry transition. The reason for this difference in June could be related to changes in the phenology, as demonstrated at a central Amazonian site (Alves et al., 2016; Lopes et al., 2016). Furthermore, during the dry season of 2015, a very strong El Niño event took place, leading to extremely dry conditions observed region-wide (Jardine et al., 2017).

It has been shown previously that the amounts and speciation of monoterpenes vary strongly according to plant species and leaf developmental stage. For instance, Bracho-Nunez et al. (2011) found young leaves of some Mediterranean plant species to emit more $\alpha$-pinene and mature leaves to emit $e$ ocimene, $z$-ocimene and myrcene, but not $\alpha$-pinene. Some species have been found to be higher emitters of $\alpha$-pinene (i.e. Hevea spruceana), whereas others are higher emitters of myrcene (i.e. Quercus coccifera Bracho-Nunez et al., 2013). The leaf developmental stage is also important, as reported 
for flushing young leaves emitting monoterpenes, in contrast to the isoprene emission of mature leaves of the same plant species (Kuhn et al., 2004). Such a behaviour could explain the lower mixing ratios and different chemodiversity found in June. During this time of the year, leaf flushing takes place in the central Amazon region (Alves et al., 2016; Lopes et al., 2016). Under these conditions, lower $\alpha$-pinene mixing ratios were found as compared to the dry season, when young leaves reach mature levels. Therefore, the seasonality in Amazon forest monoterpene emissions might depend more on the changes in aggregated canopy phenology than on the seasonality of climate drivers (Wu et al., 2016). Our study shows that chemodiversity remains relatively constant during at least the dry seasons but changed between different seasons. Therefore, the implications for the atmosphere are different for each monoterpene species. Kesselmeier et al. (2002) also showed this type of behaviour in their study, in which they did not find a strong difference in total mixing ratios, but different chemodiversity between seasons, likely expressing differences in seasonal plant developments and atmospheric reactivities, which should be accounted for in model implementations at the ATTO site.

\subsection{Modelling analysis}

To further support our analysis of the observed magnitude as well as temporal variability in the monoterpene mixing ratios inside the forest canopy, we used the MLC-CHEM (1) to explore how well the model represents the measured mixing ratios and (2) to assess the role of the different in-canopy processes in explaining the diel cycle of the observed monoterpene mixing ratios at the ATTO site.

From Fig. 6, which shows a comparison of the simulated (12.5 and $22.5 \mathrm{~m}$ ) and observed (12 and $24 \mathrm{~m})$ speciated monoterpene mixing ratios from 17 to 20 October 2015 , it can be inferred that the simulated speciated monoterpene mixing ratios are of comparable magnitude to the measured observations. This comparison regarding the magnitude of observed and simulated mixing ratios serves mainly to assess the validity of the required selection of basal emission fluxes for the different monoterpene compounds. A more relevant result seems to be the overall quite good agreement between the simulated and observed temporal variability in monoterpene mixing ratios. Note that we also conducted a simulation in which we applied temperature- and light-dependent monoterpene emission flux. However, those simulations did not follow the observed magnitudes and temporal variability as well as the model simulations considering monoterpene emissions that only depend on temperature.

The generally quite good agreement between the simulated and observed monoterpene mixing ratios, except for an overestimation of simulated $\alpha$-pinene mixing ratios for 17 October, expresses the overall result of temporally varying emissions, in-canopy chemistry, turbulent mixing and deposition. The latter also involves a potentially important role in the deposition to wet leaf surfaces (the inferred wet surface uptake resistances for the monoterpenes are $\sim 300 \mathrm{~s} \mathrm{~m}^{-1}$, similar to values reported by Zhou et al. (2017)); the MLCCHEM uses relative humidity as a proxy for the fraction of the leaf surface being wet (Lammel, 1999; Sun et al., 2016). This results in substantially smaller estimates of canopy wetness on 17 October compared to the following days, which partly explains the simulated high $\alpha$-pinene mixing ratios. The simulated $\alpha$-pinene mixing ratios for $18-20$ October, with inferred wet surface fractions up to 1 during the night and $\sim 0.5$ during daytime, are in much better agreement with the observations. Regarding the comparison of the simulated observed mixing ratios for some of the other monoterpenes, the simulated $\beta$-pinene, limonene and myrcene mixing ratios, especially at $12.5 \mathrm{~m}$ seem to capture the observed temporal variability quite well. Note that this result for limonene reflects the use of a high leaf basal emission factor $\left(0.9 \mu \mathrm{g} \mathrm{Cg}^{-1} \mathrm{~h}^{-1}\right)$ required to simulate mixing ratios reaching up to $0.4 \mathrm{ppb}$. These MLC-CHEM simulations were also used to infer how much of the actual emission flux escapes the canopy, expressed by the calculated atmospherebiosphere limonene flux divided by the canopy emission flux of limonene. This ratio reaches a maximum value of 0.5 around noon, implying that these model simulations indicate that at the middle of the day, about $50 \%$ of the emitted limonene is removed inside the canopy by in-canopy oxidation and deposition. During night-time, this ratio reaches a minimum $<0.1$, indicating simulation of very efficient incanopy removal.

These modelling results should be interpreted with caution, also given that some of the simulated processes cannot be evaluated due to missing observations of canopy wetness as well as the uptake efficiency of monoterpenes by wet surfaces. It should be considered that the simulated removal of monoterpenes by wet canopy surfaces could also compensate for a misrepresentation of other canopy processes, e.g. reduced emissions from wet canopy surfaces or an underestimation of the oxidation efficiency. Further analysis of the model-simulated process tendencies (Ganzeveld et al., 2008) indicates only small changes in the simulated source of the monoterpenes over the 4-day period. Regarding the sink of, for example, $\alpha$-pinene, chemical destruction of $\alpha$-pinene oxidation by $\mathrm{O}_{3}, \mathrm{OH}$ and $\mathrm{NO}_{3}$ appears to be a relative small term, with the overall sink being dominated by deposition to wet surfaces, showing quite large temporal variability. Consequently, the agreement between simulated and observed temporal variability in monoterpene mixing ratios that is quite reasonable indicates that deposition to wet surfaces may play an important role in monoterpene atmosphere-biosphere exchange. This should be further corroborated, calling for experiments to determine the actual efficiency (and mechanisms) of the uptake of monoterpenes by wet canopy surfaces. 


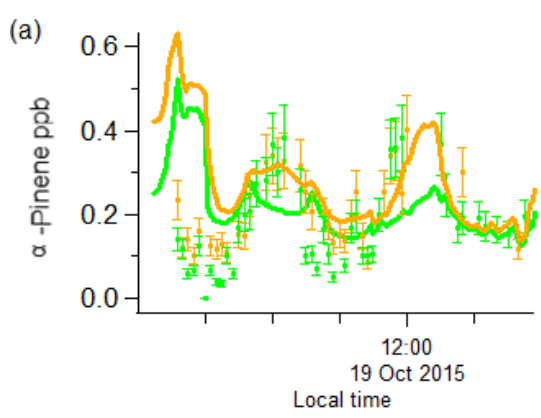

(d)

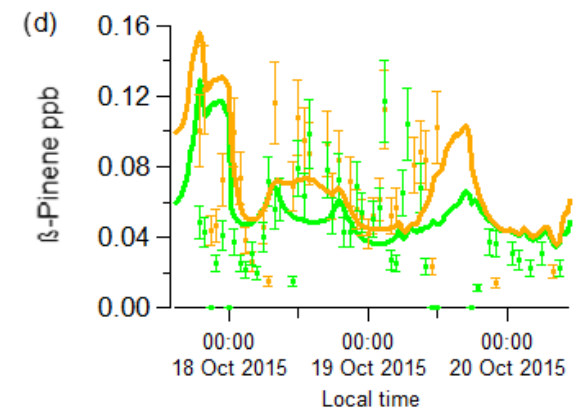

Local time

\section{Simulation at $12 \mathrm{~m}$ \\ - Simulation at $22 \mathrm{~m}$}

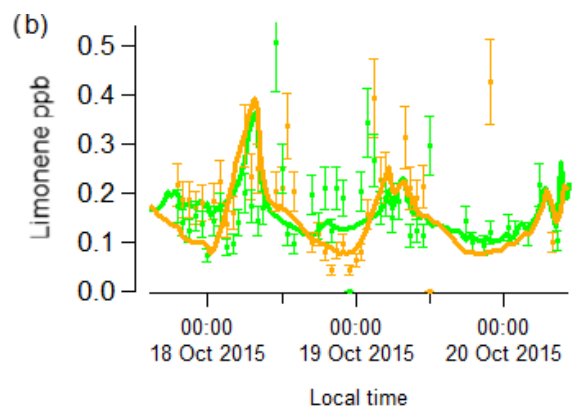

Local time

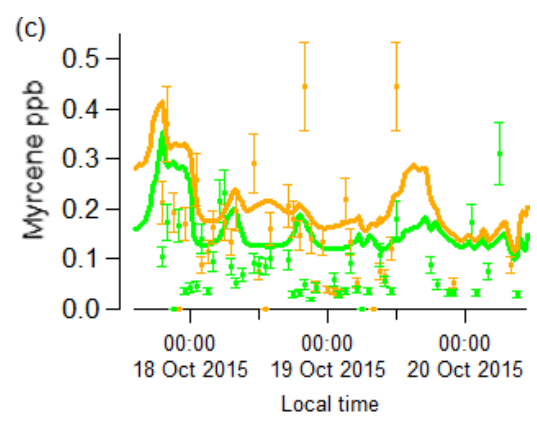

(e)

Figure 6. Comparison between simulated results (solid lines) for 12.5 (orange) and $22.5 \mathrm{~m}$ (green) from the MLC-CHEM, with the GC-FID speciated mixing ratios measurements (in ppb) for $\alpha$-pinene (a), limonene (b), myrcene (c), $\beta$-pinene (d) and $\alpha$-terpinene (e) at ATTO from 17 to 20 October 2015 . The error bars represent the $20 \%$ uncertainty involved in the GC-FID measurements.

\section{Conclusions}

This study presents an analysis of the measured monoterpene chemodiversity at the Amazon tropical forest measurement site, ATTO. The results showed a distinctly different chemical speciation between day and night, whereas there were few vertical differences in speciation within the canopy (12 and $24 \mathrm{~m}$ ). Furthermore, inter- and intra-annual results demonstrate similar chemodiversity during the dry seasons analysed, but a change of chemodiversity with season, similar to the seasonal measurements performed by Kesselmeier et al. (2002). Furthermore, reactivity calculations demonstrated that higher abundance of a monoterpene species does not automatically imply higher reactivity, as the most abundant compounds may not be the most atmospheric chemically relevant compounds, or the relative contribution of different monoterpenes may change with time. Our calculations support the view that the role of canopy exchange may be erroneously estimated when not taking speciation-based reactivity in models into account. Moreover, simulations with a canopy exchange modelling system to assess the role of canopy interactions compared relatively well with the observed temporal variability in speciated monoterpenes but also indicate the necessity of more experiments to enhance our understanding of in-canopy sinks of these compounds.
Data availability. Even though the data are still not available in any public repository, the data are available upon request from the main author.

Competing interests. The authors declare that they have no conflict of interest.

Special issue statement. This article is part of the special issue "Amazon Tall Tower Observatory (ATTO) Special Issue". It is not associated with a conference.

Acknowledgements. The authors thank the Max Planck Society and the Instituto Nacional de Pesquisas da Amazonia for continuous support. Furthermore, we acknowledge the support by the ATTO project (German Federal Ministry of Education and Research, BMBF funds 01LB1001A; Brazilian Ministério da Ciência, Tecnologia e Inovação FINEP/MCTI contract 01.11.01248.00), UEA and FAPEAM, LBA/INPA and SDS/CEUC/RDS-Uatumã. In particular, Efstratios Bourtsoukidis acknowledges the support of BmBf project ATTO (01LK1602B). We would especially like to thank all the people involved in the logistical support of the ATTO project, in particular Reiner Ditz and Hermes Braga Xavier. We acknowledge the micrometeorological group of INPA/LBA for their collaboration concerning the meteorological parameters, with special thanks to Antonio Huxley and Leonardo Oliveira. We also want to thank Matthias Sörgel, Anywhere Tsokankunku 
and Rodrigo de Souza for help with the ozone measurements. We are grateful to Nina Kropf for logistical help. We greatly acknowledge Guenther Schebeske for the GC-FID analysis. We would also like to thank Thomas Klüpfel, Tomas Chor and Emilio Hoeltgebaum for their help during sampling. This paper contains results of research conducted under the Technical/Scientific Cooperation Agreement between the National Institute for Amazonian Research, the State University of Amazonas and the Max-Planck-Gesellschaft e.V.; the opinions expressed are the entire responsibility of the authors and not of the participating institutions.

The article processing charges for this open-access publication were covered by the Max Planck Society.

Edited by: Barbara Ervens

Reviewed by: Thomas Mentel and one anonymous referee

\section{References}

Alves, E. G., Jardine, K., Tota, J., Jardine, A., Yãnez-Serrano, A. M., Karl, T., Tavares, J., Nelson, B., Gu, D., Stavrakou, T., Martin, S., Artaxo, P., Manzi, A., and Guenther, A.: Seasonality of isoprenoid emissions from a primary rainforest in central Amazonia, Atmos. Chem. Phys., 16, 3903-3925, https://doi.org/10.5194/acp-16-3903-2016, 2016.

Andreae, M. O., Artaxo, P., Brandao, C., Carswell, F. E., Ciccioli, P., da Costa, A. L., Culf, A. D., Esteves, J. L., Gash, J. H. C., Grace, J., Kabat, P., Lelieveld, J., Malhi, Y., Manzi, A. O., Meixner, F. X., Nobre, A. D., Nobre, C., Ruivo, M., Silva-Dias, M. A., Stefani, P., Valentini, R., von Jouanne, J., and Waterloo, M. J.: Biogeochemical cycling of carbon, water, energy, trace gases, and aerosols in Amazonia: The LBA-EUSTACH experiments, J. Geophys. Res., 107, 8066, https://doi.org/10.1029/2001jd000524, 2002.

Andreae, M. O., Acevedo, O. C., Araùjo, A., Artaxo, P., Barbosa, C. G. G., Barbosa, H. M. J., Brito, J., Carbone, S., Chi, X., Cintra, B. B. L., da Silva, N. F., Dias, N. L., Dias-Júnior, C. Q., Ditas, F., Ditz, R., Godoi, A. F. L., Godoi, R. H. M., Heimann, M., Hoffmann, T., Kesselmeier, J., Könemann, T., Krüger, M. L., Lavric, J. V., Manzi, A. O., Lopes, A. P., Martins, D. L., Mikhailov, E. F., Moran-Zuloaga, D., Nelson, B. W., Nölscher, A. C., Santos Nogueira, D., Piedade, M. T. F., Pöhlker, C., Pöschl, U., Quesada, C. A., Rizzo, L. V., Ro, C.-U., Ruckteschler, N., Sá, L. D. A., de Oliveira Sá, M., Sales, C. B., dos Santos, R. M. N., Saturno, J., Schöngart, J., Sörgel, M., de Souza, C. M., de Souza, R. A. F., Su, H., Targhetta, N., Tóta, J., Trebs, I., Trumbore, S., van Eijck, A., Walter, D., Wang, Z., Weber, B., Williams, J., Winderlich, J., Wittmann, F., Wolff, S., and Yáñez-Serrano, A. M.: The Amazon Tall Tower Observatory (ATTO): overview of pilot measurements on ecosystem ecology, meteorology, trace gases, and aerosols, Atmos. Chem. Phys., 15, 10723-10776, https://doi.org/10.5194/acp-15-10723-2015, 2015.

Bonn, B. and Moortgat, G. K.: Sesquiterpene ozonolysis: Origin of atmospheric new particle formation from biogenic hydrocarbons, Geophys. Res. Lett., 30, 1585, https://doi.org/10.1029/2003gl017000, 2003.

Bonn, B., Bourtsoukidis, E., Sun, T. S., Bingemer, H., Rondo, L., Javed, U., Li, J., Axinte, R., Li, X., Brauers, T., Sonderfeld,
H., Koppmann, R., Sogachev, A., Jacobi, S., and Spracklen, D. V.: The link between atmospheric radicals and newly formed particles at a spruce forest site in Germany, Atmos. Chem. Phys., 14, 10823-10843, https://doi.org/10.5194/acp-14-108232014, 2014.

Bracho-Nunez, A., Welter, S., Staudt, M., and Kesselmeier, J.: Plant-specific volatile organic compound emission rates from young and mature leaves of Mediterranean vegetation, J. Geophys. Res., 116, D16304, https://doi.org/10.1029/2010JD015521, 2011.

Bracho-Nunez, A., Knothe, N. M., Welter, S., Staudt, M., Costa, W. R., Liberato, M. A. R., Piedade, M. T. F., and Kesselmeier, J.: Leaf level emissions of volatile organic compounds (VOC) from some Amazonian and Mediterranean plants, Biogeosciences, 10, 5855-5873, https://doi.org/10.5194/bg-10-5855-2013, 2013.

Claeys, M., Graham, B., Vas, G., Wang, W., Vermeylen, R., Pashynska, V., Cafmeyer, J., Guyon, P., Andreae, M. O., Artaxo, P., and Maenhaut, W.: Formation of secondary organic aerosols through photooxidation of isoprene, Science, 303, 1173-1176, https://doi.org/10.1126/science.1092805, 2004.

Eddingsaas, N. C., Loza, C. L., Yee, L. D., Seinfeld, J. H., and Wennberg, P. O.: $\alpha$-pinene photooxidation under controlled chemical conditions - Part 1: Gas-phase composition in low- and high- $\mathrm{NO}_{x}$ environments, Atmos. Chem. Phys., 12, 6489-6504, https://doi.org/10.5194/acp-12-6489-2012, 2012.

Ehn, M., Thornton, J. A., Kleist, E., Sipilä, M., Junninen, H., Pullinen, I., Springer, M., Rubach, F., Tillmann, R., Lee, B., Lopez-Hilfiker, F., Andres, S., Acir, I.-H., Rissanen, M., Jokinen, T., Schobesberger, S., Kangasluoma, J., Kontkanen, J., Nieminen, T., Kurtén, T., Nielsen, L. B., Jørgensen, S., Kjaergaard, H. G., Canagaratna, M., Maso, M. D., Berndt, T., Petäjä, T., Wahner, A., Kerminen, V.-M., Kulmala, M., Worsnop, D. R., Wildt, J., and Mentel, T. F.: A large source of lowvolatility secondary organic aerosol., Nature, 506, 476-479, https://doi.org/10.1038/nature13032, 2014.

Engelhart, G. J., Asa-Awuku, A., Nenes, A., and Pandis, S. N.: CCN activity and droplet growth kinetics of fresh and aged monoterpene secondary organic aerosol, Atmos. Chem. Phys., 8, $3937-$ 3949, https://doi.org/10.5194/acp-8-3937-2008, 2008.

Fry, J. L., Draper, D. C., Barsanti, K. C., Smith, J. N., Ortega, J., Winkler, P. M., Lawler, M. J., Brown, S. S., Edwards, P. M., Cohen, R. C., and Lee, L.: Secondary Organic Aerosol Formation and Organic Nitrate Yield from $\mathrm{NO}_{3}$ Oxidation of Biogenic Hydrocarbons, Environ. Sci. Technol., 48, 11944-11953, https://doi.org/10.1021/es502204x, 2014.

Ganzeveld, L. and Lelieveld, J.: Impact of Amazonian deforestation on atmospheric chemistry, Geophys. Res. Lett., 31, L06105, https://doi.org/10.1029/2003GL019205, 2004.

Ganzeveld, L., Eerdekens, G., Feig, G., Fischer, H., Harder, H., Königstedt, R., Kubistin, D., Martinez, M., Meixner, F. X., Scheeren, H. A., Sinha, V., Taraborrelli, D., Williams, J., VilàGuerau de Arellano, J., and Lelieveld, J.: Surface and boundary layer exchanges of volatile organic compounds, nitrogen oxides and ozone during the GABRIEL campaign, Atmos. Chem. Phys., 8, 6223-6243, https://doi.org/10.5194/acp-8-6223-2008, 2008.

Ganzeveld, L. N., Lelieveld, J., Dentener, F. J., Krol, M. C., and Roelofs, G.-J.: Atmosphere-biosphere trace gas exchanges simulated with a single-column model, J. Geophys. Res., 107, 4297, https://doi.org/10.1029/2001JD000684, 2002. 
Gershenzon, J.: Plant volatiles carry both public and private messages, P. Natl. Acad. Sci. USA, 104, 5257-5258, https://doi.org/10.1073/pnas.0700906104, 2007.

Gershenzon, J. and Dudareva, N.: The function of terpene natural products in the natural world, Nat. Chem. Biol., 3, 408-414, https://doi.org/10.1038/nchembio.2007.5, 2007.

Ghirardo, A., Koch, K., Taipale, R., Zimmer, I. N. A., Schnitzler, J. P. Jör.-P., and Rinne, J.: Determination of de novo and pool emissions of terpenes from four common boreal/alpine trees by 13 CO 2 labelling and PTR-MS analysis, Plant. Cell Environ., 33, 781-792, https://doi.org/10.1111/j.1365-3040.2009.02104.x, 2010.

Gratien, A., Johnson, S. N., Ezell, M. J., Dawson, M. L., Bennett, R., and Finlayson-Pitts, B. J.: Surprising Formation of $p$-Cymene in the Oxidation of $\alpha$-Pinene in Air by the Atmospheric Oxidants $\mathrm{OH}, \mathrm{O}_{3}$, and $\mathrm{NO}_{3}$, Environ. Sci. Technol., 45, 2755-2760, https://doi.org/10.1021/es103632b, 2011.

Greenberg, J. P. and Zimmerman, P. R.: Nonmethane hydrocarbons in remote tropical, continental, and marine atmospheres, J. Geophys. Res., 89, 4767, https://doi.org/10.1029/JD089iD03p04767, 1984.

Griffin, R. J., Cocker, D. R., Flagan, R. C., and Seinfeld, J. H.: Organic aerosol formation from the oxidation of biogenic hydrocarbons, J. Geophys. Res., 104, 3555-3567, 1999.

Guenther, A., Karl, T., Harley, P., Wiedinmyer, C., Palmer, P. I., and Geron, C.: Estimates of global terrestrial isoprene emissions using MEGAN (Model of Emissions of Gases and Aerosols from Nature), Atmos. Chem. Phys., 6, 3181-3210, https://doi.org/10.5194/acp-6-3181-2006, 2006.

Guenther, A. B., Jiang, X., Heald, C. L., Sakulyanontvittaya, T., Duhl, T., Emmons, L. K., and Wang, X.: The Model of Emissions of Gases and Aerosols from Nature version 2.1 (MEGAN2.1): an extended and updated framework for modeling biogenic emissions, Geosci. Model Dev., 5, 1471-1492, https://doi.org/10.5194/gmd-5-1471-2012, 2012.

Hallquist, M., Wenger, J. C., Baltensperger, U., Rudich, Y., Simpson, D., Claeys, M., Dommen, J., Donahue, N. M., George, C., Goldstein, A. H., Hamilton, J. F., Herrmann, H., Hoffmann, T., Iinuma, Y., Jang, M., Jenkin, M. E., Jimenez, J. L., KiendlerScharr, A., Maenhaut, W., McFiggans, G., Mentel, T. F., Monod, A., Prévôt, A. S. H., Seinfeld, J. H., Surratt, J. D., Szmigielski, R., and Wildt, J.: The formation, properties and impact of secondary organic aerosol: current and emerging issues, Atmos. Chem. Phys., 9, 5155-5236, https://doi.org/10.5194/acp-9-51552009, 2009.

Hatakeyama, S., Izumi, K., Fukuyama, T., and Akimoto, H.: Reactions of ozone with $\alpha$-pinene and $\beta$-pinene in air: Yields of gaseous and particulate products, J. Geophys. Res., 94, 13013, https://doi.org/10.1029/JD094iD10p13013, 1989.

Helmig, D., Greenberg, J., Guenther, A., Zimmerman, P., and Geron, C.: Volatile organic compounds and isoprene oxidation products at a temperate deciduous forest site, J. Geophys. Res., 103, 22397, https://doi.org/10.1029/98JD00969, 1998.

Herrmann, F., Winterhalter, R., Moortgat, G. K., and Williams, J.: Hydroxyl radical $(\mathrm{OH})$ yields from the ozonolysis of both double bonds for five monoterpenes, Atmos. Environ., 44, 3458-3464, https://doi.org/10.1016/j.atmosenv.2010.05.011, 2010.

Hoffmann, T., Odum, J. R., Bowman, F., Collins, D., Klockow, D., Flagan, R. C., and Seinfeld, J. H.: Formation of Organic Aerosols from the Oxidation of Biogenic Hydrocarbons, J. Atmos. Chem., 26, 189-222, https://doi.org/10.1023/a:1005734301837, 1997.

Jardine, A. B., Jardine, K. J., Fuentes, J. D., Martin, S. T., Martins, G., Durgante, F., Carneiro, V., Higuchi, N., Manzi, A. O., and Chambers, J. Q.: Highly reactive light-dependent monoterpenes in the Amazon, Geophys. Res. Lett., 42, 1576-1583, https://doi.org/10.1002/2014GL062573, 2015.

Jardine, K., Yañez Serrano, A., Arneth, A., Abrell, L., Jardine, A., van Haren, J., Artaxo, P., Rizzo, L. V, Ishida, F. Y., Karl, T., Kesselmeier, J., Saleska, S., and Huxman, T.: Within-canopy sesquiterpene ozonolysis in Amazonia, J. Geophys. Res., 116, D19301, https://doi.org/10.1029/2011JD016243, 2011.

Jardine, K. J., Jardine, A. B., Holm, J. A., Lombardozzi, D. L., Negron-Juarez, R. I., Martin, S. T., Beller, H. R., Gimenez, B. O., Higuchi, N., and Chambers, J. Q.: Monoterpene "thermometer" of tropical forest-atmosphere response to climate warming, Plant. Cell Environ., 40, 441-452, https://doi.org/10.1111/pce.12879, 2017.

Jokinen, T., Berndt, T., Makkonen, R., Kerminen, V.-M., Junninen, H., Paasonen, P., Stratmann, F., Herrmann, H., Guenther, A. B., Worsnop, D. R., Kulmala, M., Ehn, M., and Sipilä, M.: Production of extremely low volatile organic compounds from biogenic emissions: Measured yields and atmospheric implications, P. Natl. Acad. Sci. USA, 112, 7123-7128, https://doi.org/10.1073/pnas.1423977112, 2015.

Karl, T., Guenther, A., Yokelson, R. J., Greenberg, J., Potosnak, M., Blake, D. R., and Artaxo, P.: The tropical forest and fire emissions experiment: Emission, chemistry, and transport of biogenic volatile organic compounds in the lower atmosphere over Amazonia, J. Geophys. Res., 112, D18302, https://doi.org/10.1029/2007JD008539, 2007.

Kesselmeier, J. and Staudt, M.: Biogenic volatile organic compounds (VOC): An overview on emission, physiology and ecology, J. Atmos. Chem., 33, 23-88, https://doi.org/10.1023/A:1006127516791, 1999.

Kesselmeier, J., Kuhn, U., Rottenberger, S., Biesenthal, T., Wolf, A., Schebeske, G., Andreae, M. O., Ciccioli, P., Brancaleoni, E., Frattoni, M., Oliva, S. T., Botelho, M. L., Silva, C. M. A., and Tavares, T. M.: Concentrations and species composition of atmospheric volatile organic compounds (VOCs) as observed during the wet and dry season in Rondonia (Amazonia), J. Geophys. Res., 107, 1-13, https://doi.org/10.1029/2000jd000267, 2002.

Kiendler-Scharr, A., Wildt, J., Dal Maso, M., Hohaus, T., Kleist, E., Mentel, T. F., Tillmann, R., Uerlings, R., Schurr, U., and Wahner, A.: New particle formation in forests inhibited by isoprene emissions., Nature, 461, 381-384, https://doi.org/10.1038/nature08292, 2009.

Kishimoto, K., Matsui, K., Ozawa, R., and Takabayashi, J.: Analysis of defensive responses activated by volatile allo-ocimene treatment in Arabidopsis thaliana, Phytochemistry, 67, 1520 1529, https://doi.org/10.1016/j.phytochem.2006.05.027, 2006.

Komenda, M.: Investigations of the emissions of monoterpenes from scots pine, Universität Köln, Jülich, 2001.

Kuhn, U., Rottenberger, S., Biesenthal, T., Wolf, A., Schebeske, G., Ciccioli, P., Brancaleoni, E., Frattoni, M., Tavares, T. M., and Kesselmeier, J.: Isoprene and monoterpene emissions of Amazonian tree species during the wet season: Direct and indirect investigations on controlling environmental functions, J. Geophys. 
Res.-Atmos., 107, 8071, https://doi.org/10.1029/2001JD000978, 2002.

Kuhn, U., Rottenberger, S., Biesenthal, T., Wolf, A., Schebeske, G., Ciccioli, P., Brancaleoni, E., Frattoni, M., Tavares, T. M., and Kesselmeier, J.: Seasonal differences in isoprene and lightdependent monoterpene emission by Amazonian tree species, Glob. Chang. Biol., 10, 663-682, https://doi.org/10.1111/j.15298817.2003.00771.x, 2004.

Kuhn, U., Dindorf, T., Ammann, C., Rottenberger, S., Guyon, P., Holzinger, R., Ausma, S., Kenntner, T., Helleis, F., and Kesselmeier, J.: Design and field application of an automated cartridge sampler for VOC concentration and flux measurements., J. Environ. Monit., 7, 568-576, https://doi.org/10.1039/b500057b, 2005.

Kuhn, U., Ganzeveld, L., Thielmann, A., Dindorf, T., Schebeske, G., Welling, M., Sciare, J., Roberts, G., Meixner, F. X., Kesselmeier, J., Lelieveld, J., Kolle, O., Ciccioli, P., Lloyd, J., Trentmann, J., Artaxo, P., and Andreae, M. O.: Impact of Manaus City on the Amazon Green Ocean atmosphere: ozone production, precursor sensitivity and aerosol load, Atmos. Chem. Phys., 10, 9251-9282, https://doi.org/10.5194/acp-10-9251-2010, 2010.

Lammel, G.: Formation of nitrous acid parameterisation and comparison with observations, Max-Planck-Inst. für Meteorologie, Hamburg, 1999.

Lerdau, M., Litvak, M., Palmer, P., and Monson, R.: Controls over monoterpene emissions from boreal forest conifers, Tree Physiol., 17, 563-569, https://doi.org/10.1093/treephys/17.8-9.563, 1997.

Lichtenthaler, H. K.: The 1-deoxy-d-xylulose-5-phosphate pathway of isoprenoid biosynthesis in plants, Annu. Rev. Plant Physiol. Plant Mol. Biol., 50, 47-65, https://doi.org/10.1146/annurev.arplant.50.1.47, 1999.

Lopes, A. P., Nelson, B. W., Wu, J., Graça, P. M. L. de A., Tavares, J. V., Prohaska, N., Martins, G. A., and Saleska, S. R.: Leaf flush drives dry season green-up of the Central Amazon, Remote Sens. Environ., 182, 90-98, https://doi.org/10.1016/j.rse.2016.05.009, 2016.

Maag, D., Erb, M., Köllner, T. G., and Gershenzon, J.: Defensive weapons and defense signals in plants: Some metabolites serve both roles, BioEssays, 37, 167-174, https://doi.org/10.1002/bies.201400124, 2015.

Malhi, Y., Roberts, J. T., Betts, R. A., Killeen, T. J., Li, W. H., and Nobre, C. A.: Climate change, deforestation, and the fate of the Amazon, Science, 319, 169-172, https://doi.org/10.1126/science.1146961, 2008.

Martin, S. T., Andreae, M. O., Artaxo, P., Baumgardner, D., Chen, Q., Goldstein, A. H., Guenther, A., Heald, C. L., Mayol-Bracero, O. L., McMurry, P. H., Pauliquevis, T., Pöschl, U., Prather, K. A., Roberts, G. C., Saleska, S. R., Silva Dias, M. A., Spracklen, D. V., Swietlicki, E., and Trebs, I.: Sources and properties of Amazonian aerosol particles, Rev. Geophys., 48, RG2002, https://doi.org/10.1029/2008RG000280, 2010.

Mentel, Th. F., Wildt, J., Kiendler-Scharr, A., Kleist, E., Tillmann, R., Dal Maso, M., Fisseha, R., Hohaus, Th., Spahn, H., Uerlings, R., Wegener, R., Griffiths, P. T., Dinar, E., Rudich, Y., and Wahner, A.: Photochemical production of aerosols from real plant emissions, Atmos. Chem. Phys., 9, 4387-4406, https://doi.org/10.5194/acp-9-4387-2009, 2009.
Neeb, P., Bode, K., Beck, J., Schafer, L., Kesselmeier, J., and Moortgat: Influence of gas-phase oxidation on estimated emission rates of biogenic hydrocarbons, in: The Oxidizing Capacity of the Atmosphere,Proceedings Physico-Chemical, of the 7th European Symposium on the Behaviour of Atmospheric Pollutants, EUR 17482, edited by: Larsen, B., Versino, B., and Angeletti, G., 295299, Office for Official Publications of the European Communities, Brussels, Belgium, 1997.

Nölscher, A. C., Yañez-Serrano, A. M., Wolff, S., de Araujo, A. C., Lavrič, J. V., Kesselmeier, J., and Williams, J.: Unexpected seasonality in quantity and composition of Amazon rainforest air reactivity, Nat. Commun., 7, 10383, https://doi.org/10.1038/ncomms10383, 2016.

O’Dowd, C. D., Aalto, P., Hameri, K., Kulmala, M., and Hoffmann, T.: Aerosol formation - Atmospheric particles from organic vapours, Nature, 416, 497-498, 2002.

Ormeno, E., Fernandez, C., Bousquet-Melou, A., Greff, S., Morin, E., Robles, C., Vila, B., and Bonin, G.: Monoterpene and sesquiterpene emissions of three Mediterranean species through calcareous and siliceous soils in natural conditions, Atmos. Environ., 41, 629-639, https://doi.org/10.1016/j.atmosenv.2006.08.027, 2007.

Paulson, S. E., Chung, M. Y., and Hasson, A. S.: OH Radical Formation from the Gas-Phase Reaction of Ozone with Terminal Alkenes and the Relationship between Structure and Mechanism, J. Phys. Chem. A, 103, 8125-8138, https://doi.org/10.1021/jp991995e, 1999.

Penuelas, J. and Llusia, J.: Linking photorespiration, monoterpenes and thermotolerance in Quercus, New Phytol., 155, 227-237, https://doi.org/10.1046/j.1469-8137.2002.00457.x, 2002.

Pöschl, U., Martin, S. T., Sinha, B., Chen, Q., Gunthe, S. S., Huffman, J. A., Borrmann, S., Farmer, D. K., Garland, R. M., Helas, G., Jimenez, J. L., King, S. M., Manzi, A., Mikhailov, E., Pauliquevis, T., Petters, M. D., Prenni, A. J., Roldin, P., Rose, D., Schneider, J., Su, H., Zorn, S. R., Artaxo, P., Andreae, M. O., Poschl, U., Martin, S. T., Sinha, B., Chen, Q., Gunthe, S. S., Huffman, J. A., Borrmann, S., Farmer, D. K., Garland, R. M., Helas, G., Jimenez, J. L., King, S. M., Manzi, A., Mikhailov, E., Pauliquevis, T., Petters, M. D., Prenni, A. J., Roldin, P., Rose, D., Schneider, J., Su, H., Zorn, S. R., Artaxo, P., and Andreae, M. O.: Rainforest Aerosols as Biogenic Nuclei of Clouds and Precipitation in the Amazon, Science, 329, 15131516, https://doi.org/10.1126/science.1191056, 2010.

Rinne, H. J. I., Guenther, A. B., Greenberg, J. P., and Harley, P. C.: Isoprene and monoterpene fluxes measured above Amazonian rainforest and their dependence on light and temperature, Atmos. Environ., 36, 2421-2426, https://doi.org/10.1016/S13522310(01)00523-4, 2002.

Sarrafzadeh, M., Wildt, J., Pullinen, I., Springer, M., Kleist, E., Tillmann, R., Schmitt, S. H., Wu, C., Mentel, T. F., Zhao, D., Hastie, D. R., and Kiendler-Scharr, A.: Impact of $\mathrm{NO}_{x}$ and $\mathrm{OH}$ on secondary organic aerosol formation from $\beta$ pinene photooxidation, Atmos. Chem. Phys., 16, 11237-11248, https://doi.org/10.5194/acp-16-11237-2016, 2016.

Schwender, J., Seemann, M., Lichtenthaler, H. K., and Rohmer, M.: Biosynthesis of isoprenoids (carotenoids, sterols, prenyl sidechains of chlorophylls and plastoquinone) via a novel pyruvate/glyceraldehyde 3-phosphate non-mevalonate pathway in the 
green alga Scenedesmus obliquus, Biochem. J., 316, 73-80, https://doi.org/10.1042/bj3160073, 1996.

Spivakovsky, C. M., Logan, J. A., Montzka, S. A., Balkanski, Y. J., Foreman-Fowler, M., Jones, D. B. A., Horowitz, L. W., Fusco, A. C., Brenninkmeijer, C. A. M., Prather, M. J., Wofsy, S. C., and McElroy, M. B.: Three-dimensional climatological distribution of tropospheric $\mathrm{OH}$ : Update and evaluation, J. Geophys. Res.-Atmos., 105, 8931-8980, https://doi.org/10.1029/1999JD901006, 2000.

Sternberg, J. C., Gallaway, W. S., and Jones, D. T. L.: The mechanism of response of flame ionisation detectors, in: Gas Chromatography, edited by: Brenner, N., Callin, J. E., and Weiss, M. D., Academic press, New York, 1962.

Sun, S., Moravek, A., von der Heyden, L., Held, A., Sörgel, M., and Kesselmeier, J.: Twin-cuvette measurement technique for investigation of dry deposition of $\mathrm{O}_{3}$ and PAN to plant leaves under controlled humidity conditions, Atmos. Meas. Tech., 9, 599-617, https://doi.org/10.5194/amt-9-599-2016, 2016.

Vickers, C. E., Gershenzon, J., Lerdau, M. T., and Loreto, F.: A unified mechanism of action for volatile isoprenoids in plant abiotic stress, Nat. Chem. Biol., 5, 283-291, https://doi.org/10.1038/nchembio.158, 2009.

Wesely, M. L.: Parameterization of surface resistances to gaseous dry deposition in regional-scale numerical models, Atmos. Environ., 23, 1293-1304, https://doi.org/10.1016/00046981(89)90153-4, 1989.

Wildt, J., Mentel, T. F., Kiendler-Scharr, A., Hoffmann, T., Andres, S., Ehn, M., Kleist, E., Müsgen, P., Rohrer, F., Rudich, Y., Springer, M., Tillmann, R., and Wahner, A.: Suppression of new particle formation from monoterpene oxidation by $\mathrm{NO}_{x}$, Atmos. Chem. Phys., 14, 2789-2804, https://doi.org/10.5194/acp14-2789-2014, 2014.

Williams, J., Yassaa, N., Bartenbach, S., and Lelieveld, J.: Mirror image hydrocarbons from Tropical and Boreal forests, Atmos. Chem. Phys., 7, 973-980, https://doi.org/10.5194/acp-7973-2007, 2007.
Williams, J., Keßel, S. U., Nölscher, A. C., Yang, Y., Lee, Y., Yáñez-Serrano, A. M., Wolff, S., Kesselmeier, J., Klüpfel, T., Lelieveld, J., and Shao, M.: Opposite $\mathrm{OH}$ reactivity and ozone cycles in the Amazon rainforest and megacity Beijing: Subversion of biospheric oxidant control by anthropogenic emissions, Atmos. Environ., 125, 112-118, https://doi.org/10.1016/j.atmosenv.2015.11.007, 2016.

Wu, J., Albert, L. P., Lopes, A. P., Restrepo-Coupe, N., Hayek, M., Wiedemann, K. T., Guan, K., Stark, S. C., Christoffersen, B., Prohaska, N., Tavares, J. V., Marostica, S., Kobayashi, H., Ferreira, M. L., Campos, K. S., da Silva, R., Brando, P. M., Dye, D. G., Huxman, T. E., Huete, A. R., Nelson, B. W., and Saleska, S. R.: Leaf development and demography explain photosynthetic seasonality in Amazon evergreen forests, Science, 351, 972-976, https://doi.org/10.1126/science.aad5068, 2016.

Yáñez-Serrano, A. M., Nölscher, A. C., Williams, J., Wolff, S., Alves, E. G., Martins, G. A., Bourtsoukidis, E., Brito, J., Jardine, K., Artaxo, P., and Kesselmeier, J.: Diel and seasonal changes of biogenic volatile organic compounds within and above an Amazonian rainforest, Atmos. Chem. Phys., 15, 3359-3378, https://doi.org/10.5194/acp-15-3359-2015, 2015.

Zhao, D. F., Kaminski, M., Schlag, P., Fuchs, H., Acir, I.-H., Bohn, B., Häseler, R., Kiendler-Scharr, A., Rohrer, F., Tillmann, R., Wang, M. J., Wegener, R., Wildt, J., Wahner, A., and Mentel, T. F.: Secondary organic aerosol formation from hydroxyl radical oxidation and ozonolysis of monoterpenes, Atmos. Chem. Phys., 15, 991-1012, https://doi.org/10.5194/acp-15-991-2015, 2015.

Zhou, P., Ganzeveld, L., Taipale, D., Rannik, Ü., Rantala, P., Rissanen, M. P., Chen, D., and Boy, M.: Boreal forest BVOC exchange: emissions versus in-canopy sinks, Atmos. Chem. Phys., 17, 14309-14332, https://doi.org/10.5194/acp-17-143092017, 2017. 